\title{
Economic Losses from Heat Stress by US Livestock Industries ${ }^{1}$
}

\author{
N. R. St-Pierre*, B. Cobanov*, and G. Schnitkey† \\ ${ }^{*}$ Department of Animal Sciences \\ The Ohio State University, Columbus, $\mathrm{OH} 43210$ \\ †Department of Agricultural and Consumer Economics \\ University of Illinois, Urbana, IL 61801
}

\begin{abstract}
Economic losses are incurred by the US livestock industries because farm animals are raised in locations and seasons where effective temperature conditions venture outside their zone of thermal comfort. The objective of this review was to estimate economic losses sustained by major US livestock industries from heat stress. Animal classes considered were: dairy cows, dairy heifers ( 0 to $1 \mathrm{yr}$ and 1 to $2 \mathrm{yr}$ ), beef cows, finishing cattle, sows, market hogs, broilers, layers, and turkeys. Economic losses considered were: 1 ) decreased performance (feed intake, growth, milk, eggs), 2) increased mortality, and 3) decreased reproduction. USDA and industry data were used for monthly inventories of each animal class in each of the contiguous 48 states. Daily weather data from 257 weather stations over a range of 68 to $129 \mathrm{yr}$ were used to estimate mean monthly maximum and minimum temperatures, relative humidity, and their variances and covariances for each state. Animal responses were modeled from literature data using a combination of maximum temperaturehumidity index, daily duration of heat stress, and a heat load index. Monte Carlo techniques were used to simulate 1000 times the weather for each month of the year, for each animal class, for each state, and for each of four intensities of heat abatement (minimum, moderate, high, and intensive). Capital and operating costs were accounted for each heat abatement intensity. Without heat abatement (minimum intensity), total losses across animal classes averaged $\$ 2.4$ billion annually. Optimum heat abatement intensity reduced annual total losses to $\$ 1.7$ billion. Annual losses averaged $\$ 897$ million, \$369 million, \$299 million, and \$128 million for dairy, beef, swine, and poultry industries, respectively. Across states, Texas, California, Oklahoma,
\end{abstract}

Received August 8, 2002.

Accepted December 2, 2002.

Corresponding author: N. R. St-Pierre; e-mail: st-pierre.8@ osu.edu.

${ }^{1}$ Salaries and research support were provided by state and federal funds appropriated to Ohio Agricultural Research and Development Center, The Ohio State University. Manuscript No. 31-02AS.
Nebraska, and North Carolina accounted for $\$ 728$ million of annual losses, or $43 \%$ of total national losses. Results point to a need for more energy and capital efficient heat abatement systems.

(Key words: heat stress, temperature-humidity index, livestock economics, livestock production)

Abbreviation key: $\mathbf{D M I}_{\text {Loss }}=$ the reduction in DMI from heat stress (kg per animal or per 1000 birds per day), $\mathbf{D O}_{\text {Loss }}=$ the change in the average number of days open from heat stress, $\Delta \mathbf{T H I}=$ the change in apparent THI from a heat abatement system, $\mathbf{E G G}_{\mathbf{L o s s}}$ $=$ the loss in egg production from heat stress $(\mathrm{kg}$ per

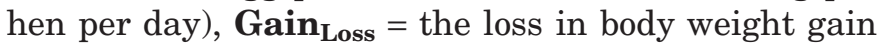
(kilogram per animal or per 1000 birds per day), $\mathbf{H}=$ relative humidity (\%), PDeath = the change in monthly death rate from heat stress, $\mathbf{P R}=$ monthly pregnancy rate, $\mathbf{R C u l l R a t e}=$ the change in monthly reproductive cull rate due to heat stress, $\mathbf{T}=$ temperature $\left({ }^{\circ} \mathrm{C}\right), \mathbf{T H I}$ = temperature-humidity index, $\mathbf{T H I}_{\mathbf{L o a d}}=$ integral of the daily $\mathrm{THI}$ sine curve above $\mathrm{THI}_{\text {threshold }}, \mathbf{T H I}_{\text {Loadm }}=$ the average monthly $\mathrm{THI}_{\text {Load }}, \mathbf{T H I}_{\mathbf{m a x}}=$ daily maximum THI, THI $_{\text {min }}=$ daily minimum THI, THI $_{\text {threshold }}=$ THI threshold above which heat stress occurs in a given animal class, ZTC = zone of thermal comfort.

\section{INTRODUCTION}

Environments of high temperatures and humidity are detrimental to the productivity of commercial animal agriculture (Fuquay, 1981; Morrison, 1983). Farm animals have known zones of thermal comfort (ZTC) that are primarily dependent on the species, the physiological status of the animals, the relative humidity, and velocity of ambient air, and the degree of solar radiation (NRC, 1981). Economic losses are incurred by the US livestock industries because farm animals are raised in places and seasons where temperature conditions venture outside the ZTC. Heat stress results from a negative balance between the net amount of energy flowing from the animal to its surrounding environment and the amount of heat energy produced by the animal. This imbalance is induced by changes in a combination of environmental factors (e.g., sunlight, thermal radia- 
tion, air temperature), animal properties (e.g., rate of metabolism and moisture loss) and thermoregulatory mechanisms such as conduction, radiation, convection, and evaporation. The importance of heat stress to US livestock industries is increasing with time because of the long-term trend shift in the location where animal agriculture is primarily located and because animals of better genotype produce more body heat due to their greater metabolic activity (West, 1994; Settar et al., 1999).

Much work has been done to identify the physiological effects of heat stress and the mechanisms by which animal productivity is reduced. In dairy, heat stress consistently result in reduced DMI (West, 1994) and this effect is generally greater in pluriparous than in primiparous cows (Holter et al., 1996, 1997). The extent of production loss is often difficult to estimate because heat stress effects are typically hidden among high natural and managerial sources of variation (du Preez et al., 1990c; Linvill and Pardue, 1992), plus other confounding factors, such as stage of lactation, breed, and age (Ray et al., 1992; Ravagnolo and Misztal, 2000; Ravagnolo et al., 2000), and carryover effects (Collier et al., 1982a).

Heat stress reduces the expression of estrous behavior (Hansen et al., 2001), alters follicular development (Wise, et al., 1988; Wolfenson et al., 1995) and the growth and function of the dominant follicle (Wilson et al., 1998a, 1998b), compromises oocyte competence (Collier et al., 1982b; Wolfenson et al., 2000), and inhibits embryonic development (Drost et al., 1999). The quantification of the effect of heat stress is further complicated because it has both a concurrent and delayed effect on the reproductive system (Wolfenson et al., 1997; Rotz et al., 2000, 2001). Consequently, heat stress reduces fertility of female (Folman et al., 1983) and male cattle (Ax et al., 1987), resulting in reduced reproductive performance (Monty and Wolf, 1974; Salah and Mogawer, 1990).

The incidence of new udder infections and frequency of mastitis increases during hot summer months because the udder's defense mechanisms become deficient (Giesecke, 1985). Cow mortality increases during periods of heat stress (Hahn, 1985), but the quantitative relationship between mortality risk and magnitude of heat stress remains to be defined. The quantification of the effects of heat stress on dairy cattle is further complicated because cattle have the ability to acclimate to changes in the environment (Wolfenson et al., 1988; du Preez et al., 1990c), genetics plays a role in tolerance to heat stress (du Preez, 2000; McDowell et al., 1996), current selection for production reduces heat tolerance in the United States (Ravagnolo and Mitsztal, 2000), and nutrition and management strategies can reduce its effect (Coppock et al., 1982; Schneider et al., 1984; Knapp and Grummer, 1991).

Most of the effects of heat stress identified in dairy cattle are also present in beef cattle, albeit to a lesser extent due to the overall lower body heat production (lower plane of production) of beef cows combined with a traditional breeding season during which the incidence of heat stress is low. In growing cattle, heat stress has decreased DMI, increased DM digestibility (Lippke, 1975), decreased rate of gain (Ray, 1989; Mitlohner et al., 2001) partially negated by compensatory gain (Mader et al., 1999), and reduced fertility of males (Meyerhoeffer et al., 1985) and females (Biggers et al., 1987). Quantification of these effects is complicated by acclimation of animals (Robinson et al., 1986) and breed differences in their susceptibility to heat stress (Hammond et al., 1998; Gaugham et al., 1999).

In sows, heat stress has consistently been associated with decreased DMI, milk yield, and increased sow lactation BW loss while reducing the weight gain of the litter preweaning (McGlone et al., 1988b; Johnston et al., 1999; Renaudeau and Noblet, 2001; Renaudeau et al., 2001). Litter size, however, is either unaffected (Johnston et al., 1999) or is increased by heat stress (McGlone et al., 1988b) due to decreased piglet mortality. Additionally, piglets from sows under heat stress exhibit strong compensatory weight gains postweaning, essentially negating most of the heat stress effect while suckling by 2 wk postweaning (Renaudeau and Noblet, 2001; Renaudeau et al., 2001). The sow reproductive system is sensitive to heat stress pre- and postmating. Heat stress affects fertility of both male and female pigs for up to 5 wk after a stressful event (Wettemann and Bazer, 1985). Embryo development is compromised with heat stress (Kojima et al., 1996), and the proportion of sows showing delayed return or failure to return to estrus after mating is increased noticeably (Hennessy and Williamson, 1984; Gross et al., 1989; Liao and Veum, 1994). Sow mortality also has been associated with heat stress (D'Allaire et al., 1996). Nutrition can mitigate some of the effects of heat stress in sows. Fiber addition to the diet increases, but fat addition decreases, the impact of heat stress on sows (Schoenherr et al., 1989). During growth, young gilts are not affected much by heat stress until breeding time, at which heat stress has the same depressive effect on reproduction as in older animals (Flowers et al., 1989). Severe heat stress can also affect the growth of market pigs, although acclimation is a factor (Collin et al., 2001). During periods of heat stress, growing pigs reduce fasting heat production by $18 \%$, daily heat production by $22 \%$, and thermic effect of feed by $35 \%$ (Collin et al., 2001). Social stressors (regrouping) magnify growth 
and intake depression resulting from heat stress (McClone et al., 1987).

Prolonged, severe heat stress affects DMI and daily gain of broiler chickens, especially after $28 \mathrm{~d}$ of age (Cooper and Washburn, 1998; Yalcin et al., 2001a). The ZTC in broiler chickens, especially under 4 wk of age, is substantially greater than that of most other commercial farm animals (NRC, 1981). Additionally, acclimation to high thermal conditions at an early age (4 to 7 d) noticeably reduces the effect of heat stress at a later age (Yahav and Plavnik, 1999; Altan et al., 2000; Yalcin et al., 2001a). Acclimation reduced heat production by $11.4 \%$ and evaporative heat loss by $14.8 \%$ (Wiernusz and Teeter, 1996), and lowers heat stress mortality (May et al., 1987). Thyroid size is reduced in birds grown under heat stress, especially if heat stress is cyclic (Dale and Fuller, 1980). Heat stress during rapid growth has also been associated with undesirable meat characteristics (Sandercock et al., 2001). Male broiler breeders are affected more by heat stress than females (McDaniel et al., 1995). Bird mortality increases during heat stress (Bogin et al., 1996; De Basilio et al., 2001) and is greater near marketing time and in the presence of some anticoccidial drugs (McDouglad and McQuistion, 1980; Arjona et al., 1998), as well as during transportation to central processing plants (Mitchell and Kettlewell, 1998).

Research on heat stress in laying hens is not entirely consistent regarding its effects on percent hen-day production, but results show a consistent decrease in egg weight and shell thickness (Wolfenson et al., 1979; Emery et al., 1984; Muiruri and Harrison, 1991; Wolfenson et al., 2001). Acclimation to heat stress in layers is pronounced (Sykes and Fataftak, 1985, 1986; Sykes and Salih, 1986). Dietary parameters can modulate the effect of diet stress (Bollengier-Lee et al., 1998; Bollengier-Lee et al., 1999; Sahin et al., 2002) as well as management factors (Kassim and Sykes, 1982; Sahin and Kucuk, 2001).

Literature on heat stress in turkeys relates primarily to mortality (Evans et al., 2000) and the association between heat stress and the incidence of pale, exudative meat (McKee and Sams, 1997; Owens et al., 2000).

In all, research has identified many of the mechanisms by which heat stress affects the different classes of farm livestock. Recommendations regarding housing, ventilation, and cooling systems are now issues that are probably applicable on a regional basis (Flamenbaum et al., 1985; Lin et al., 1998; Armstrong et al., 1999). Some economic analyses have been done, but they failed to recognize that capital costs of cooling systems are incurred even during periods when heat stress is absent (Igono et al., 1987). Efforts are under way to quantify livestock responses for heat stress management (Mayer et al., 1999; Nienaber et al., 1999), although these efforts are not inclusive of all farm animals of economic importance. Currently, there are no known estimates of the total economic losses to US livestock industries that are attributable to heat stress. An estimation of such losses would serve in assessing the need for public research investments in heat stress abatement and could be used as a quantitative platform to issue regional recommendations for the various classes of food producing animals. The objectives of the present study are to provide estimates of national and regional economic losses from heat stress by major US food-producing animal industries and to identify areas for which information is lacking to adequately quantify important processes.

\section{RESEARCH AND METHODS}

\section{Weather Data}

Daily weather records from 257 weather stations starting between 1871 and 1932 were used to estimate means, variances, and covariances of monthly minimum and maximum temperatures, minimum and maximum relative humidity, and calculated minimum and maximum temperature-humidity index (THI) for each of the 48 contiguous states. Weather data were retrieved from the National Oceanic and Atmospheric Administration archives of data originally recorded by the National Weather Service's Cooperative Station network. Within days, temperature and relative humidity were assumed counter-cyclical; thus, minimum THI

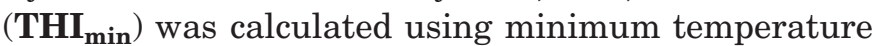
and maximum humidity, whereas maximum THI (THImax ) was calculated using maximum temperature and minimum humidity using the standard THI equation (Ravagnolo et al., 2000).

To account for the extent and cumulative severity of heat stress within days, two additional variables were calculated (Figure 1). The temperature-humidity index was assumed to follow a perfect sine function with a period of $24 \mathrm{~h}$. This assumption underestimates duration of heat stress at higher latitudes in summer time, but gains in accuracy with more complex models (e.g., Linvill and Pardue, 1992) are overall small. A THI thres- $_{\text {- }}$ hold was identified for each class of animal (Table 1) and is defined as the THI level at which heat stress begins. Using $\mathrm{THI}_{\min }, \mathrm{THI}_{\max }$, and $\mathrm{THI}_{\text {threshold }}$, duration (D) of heat stress and time summation of THI in excess

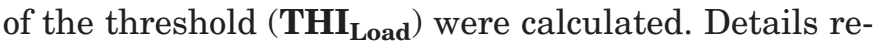
garding the calculation of $\mathrm{D}$ and $\mathrm{THI}_{\mathrm{Load}}$ are provided in Appendix in the form of a computer code. 


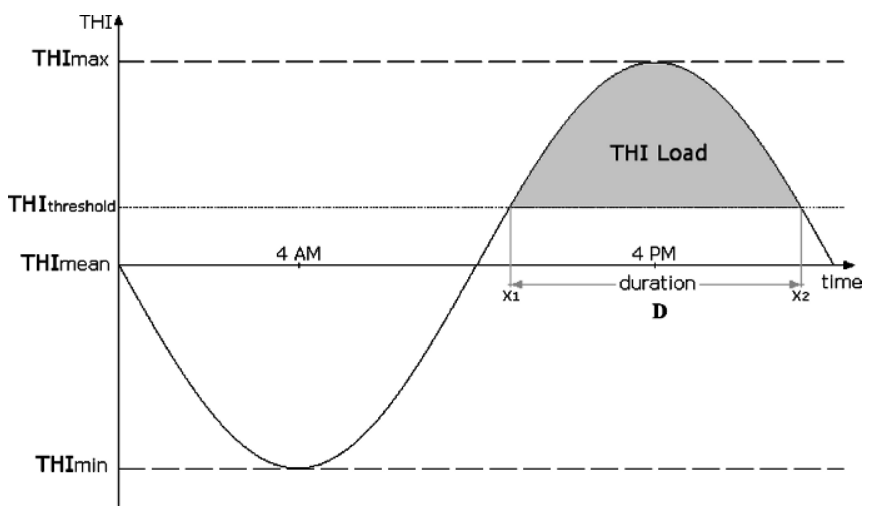

Figure 1. Sine model of the temperature-humidity index (THI) within a day and the calculation of duration of heat stress and cumulative heat load (THILoad); THI $_{\max }$ is the maximum THI during a day; $\mathrm{THI}_{\text {threshold }}$ is the THI limit above which heat stress begins; $\mathrm{THI}_{\text {mean }}$ is the mean daily $\mathrm{THI}$; $\mathrm{THI}_{\min }$ is the minimum THI during a day; $\mathrm{D}$ is the proportion of the day in which THI exceeds $\mathrm{THI}_{\text {threshold; }}$ THIload is the integral of the THI sine curve above $\mathrm{THI}_{\text {threshold }}$.

\section{Animal Population}

Ten animal classes were considered of economic importance to the US livestock industries: dairy cows, dairy replacement heifers ( 0 to $1 \mathrm{yr}$ and 1 to $2 \mathrm{yr}$ ), beef cows, finishing cattle, sows, market hogs, broilers, layers and turkeys. Annual inventory and production data for yr 2000 were estimated from USDA National Agricultural Statistics Service and industry reports (Lobo, 2001). Annual inventory and production data were transformed to monthly inventories assuming 2.2 farrowings/sow per year, two cycles of growing-finishing hogs per year, six cycles of broilers per year, and 2.5 cycles of turkeys per year. The resulting monthly animal inventories are reported in Table 2. Births of animals were assumed uniform throughout the year with the exception of beef cattle from which $75 \%$ of the breedings were modeled to occur during the spring season.

\section{Dairy Cow Model}

Studies used to develop biological response functions to heat stress in dairy cattle are reported in Table 3. For dairy cows, the following set of equations was used:

$$
\begin{aligned}
\mathrm{DMI}_{\text {Loss }}= & 0.0345 \times\left(\mathrm{THI}_{\max }-\mathrm{THI}_{\text {threshold }}\right)^{2} \times \mathrm{D} \quad[1] \\
\mathrm{MILK}_{\mathrm{Loss}}= & 0.0695 \times\left(\mathrm{THI}_{\max }-\mathrm{THI}_{\text {threshold }}\right)^{2} \times \mathrm{D} \\
\mathrm{PR}= & 0.20-0.00090 \times \mathrm{THI}_{\text {Loadm }} \\
\mathrm{DO}_{\text {Loss }}= & 164.5-(184.5 \times \mathrm{PR})+\left(29.38 \times \mathrm{PR}^{2}\right)- \\
& 128.8 \\
\text { RCullRate }= & 100-102.7 \times(1-1.101 \times \mathrm{EXP}(10.19 \times \\
& \mathrm{PR})) \\
\text { PDeath }= & 0.000855 \times \operatorname{EXP}\left(0.00981 \times \mathrm{THI}_{\text {Loadm }}\right)
\end{aligned}
$$

where

$\mathbf{D M I}_{\text {Loss }}$ is the reduction in DMI from heat stress (kilogram per animal per day),

$\mathrm{THI}_{\max }$ is the maximum THI during a day, $\mathrm{THI}_{\text {threshold }}$ is the THI threshold, above which heat stress occurs for dairy cows,

$\mathrm{D}$ is the proportion of a day where $\mathrm{THI}>$ $\mathrm{THI}_{\text {threshold }}$ (e.g., 0.33),

Milk $_{\text {Loss }}$ is the reduction in milk production (kilogram per cow per day),

$\mathbf{P R}$ is the monthly pregnancy rate (e.g.

\begin{tabular}{|c|c|c|c|c|c|c|}
\hline Animal class & THI $_{\text {threshold }}$ & $\begin{array}{l}\mathrm{DMI}_{\mathrm{Loss}} \$ \\
(\$ / \mathrm{kg})\end{array}$ & $\begin{array}{l}\text { Output }_{\text {Loss }} \$ \\
\text { (\$/unit) }\end{array}$ & $\begin{array}{l}\mathrm{DO}_{\text {Loss } \$} \\
(\$ / \mathrm{d})\end{array}$ & $\begin{array}{l}\text { Rcull }_{\text {Loss } \$} \\
\text { (\$/unit) }\end{array}$ & $\begin{array}{l}\text { Death\$ } \\
\text { (\$/unit) }\end{array}$ \\
\hline Dairy cow & 70 & 0.13 & 0.287 & 2.50 & 1,200 & 1,800 \\
\hline Dairy heifers ( 0 to1) & 77 & 0.11 & 2.20 & $\ldots$ & $\ldots$ & 900 \\
\hline Dairy heifers ( 1 to 2 ) & 72 & 0.088 & 2.20 & $\ldots$ & $\ldots$ & 1,350 \\
\hline Beef cows & 75 & & $\ldots$ & 1.80 & 700 & 1,200 \\
\hline Finishing beef & 72 & 0.10 & 1.54 & 0 & 0 & 600 \\
\hline Sows & 74 & & $\ldots$ & 1.50 & . & 250 \\
\hline Growing-finishing hogs & 72 & 0.11 & 1.00 & $\ldots$ & $\ldots$ & 60 \\
\hline Poultry broiler chickens & 78 & 0.13 & 1.21 & $\ldots$ & $\ldots$ & 2 \\
\hline Poultry layers & 70 & 0.125 & 0.50 & $\ldots$ & $\ldots$ & 2.5 \\
\hline Poultry turkeys & 78 & 0.138 & 1.59 & $\ldots$ & $\ldots$ & 10 \\
\hline
\end{tabular}
$0.15)$,

THI $_{\text {Loadm }}$ is the monthly average $\mathrm{THI}_{\text {Load }}$,

DO $_{\text {Loss }}$ is the change in the average number of days open,

RCullRate is the change in monthly cull rate (e.g., 0.01 ),

Table 1. Physical and economic values used for modeling the economic impact of heat stress. ${ }^{1}$

${ }^{1} \mathrm{THI}$ is the temperature-humidity index; $\mathrm{THI}_{\text {threshold }}$ is the THI threshold above which heat stress occurs for that animal class; $\mathrm{DMI}_{\mathrm{Loss} \$}$ is the unit price of DMI for that animal class; Ouput $\mathrm{Loss}_{\mathbf{1}}$ is the price of one unit of output (gain, milk, doz. eggs) for that animal class; $\mathrm{DO}_{\mathrm{Loss} \$}$ is the price for one day open for that

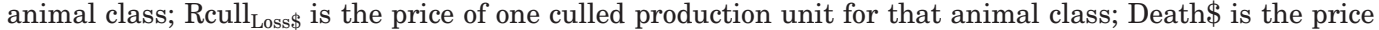
of one dead animal in that animal class. 
Table 2. Monthly animal inventory (in thousands) by animal class and by state.

\begin{tabular}{|c|c|c|c|c|c|c|c|c|c|c|}
\hline State & $\begin{array}{l}\text { Dairy } \\
\text { cows }\end{array}$ & $\begin{array}{l}\text { Dairy } \\
\text { heifers, } \\
0 \text { to } 1 \text { yr }\end{array}$ & $\begin{array}{l}\text { Dairy } \\
\text { heifers, } \\
1 \text { to } 2 \mathrm{yr}\end{array}$ & $\begin{array}{l}\text { Beef } \\
\text { cows }\end{array}$ & $\begin{array}{l}\text { Beef, } \\
\text { finishing } \\
\text { cattle }\end{array}$ & $\begin{array}{l}\text { Swine } \\
\text { sows }\end{array}$ & $\begin{array}{l}\text { Swine, } \\
\text { growing- } \\
\text { finishing }\end{array}$ & $\begin{array}{l}\text { Poultry, } \\
\text { broilers }\end{array}$ & $\begin{array}{l}\text { Poultry, } \\
\text { layers }\end{array}$ & $\begin{array}{l}\text { Poultry, } \\
\text { turkeys }\end{array}$ \\
\hline $\mathrm{AL}$ & 23 & 9 & 9 & 737 & 0 & 13 & 122 & 173,117 & 10,413 & 0 \\
\hline $\mathrm{AZ}$ & 140 & 32 & 31 & 195 & 335 & 11 & 113 & 0 & 0 & 0 \\
\hline $\mathrm{CA}$ & 1560 & 769 & 750 & 780 & 608 & 18 & 186 & 87,388 & 24,056 & 0 \\
\hline $\mathrm{CO}$ & 90 & 46 & 45 & 840 & 2680 & 159 & 1479 & 0 & 3671 & 7200 \\
\hline $\mathrm{CT}$ & 26 & 12 & 12 & 8 & 0 & 0 & 5 & 0 & 3129 & 2 \\
\hline GA & 86 & 32 & 31 & 614 & 0 & 46 & 448 & 204,950 & 20,816 & 0 \\
\hline IA & 215 & 118 & 115 & 985 & 606 & 859 & 8376 & 0 & 28,098 & 2840 \\
\hline ID & 354 & 164 & 160 & 496 & 700 & 2 & 21 & 0 & 893 & 0 \\
\hline IL & 118 & 62 & 60 & 452 & 0 & 375 & 3595 & 0 & 3549 & 1160 \\
\hline IN & 151 & 64 & 62 & 229 & 0 & 277 & 2685 & 0 & 22,708 & 5400 \\
\hline $\mathrm{KS}$ & 96 & 72 & 70 & 1524 & 5370 & 143 & 1378 & 0 & 1578 & 2400 \\
\hline $\mathrm{KY}$ & 130 & 41 & 40 & 1060 & 0 & 41 & 388 & 34,700 & 3769 & 0 \\
\hline MI & 300 & 133 & 130 & 85 & 0 & 87 & 862 & 0 & 6238 & 1400 \\
\hline $\mathrm{MN}$ & 520 & 297 & 290 & 410 & 0 & 473 & 4655 & 7367 & 12,581 & 17,400 \\
\hline MO & 150 & 67 & 65 & 2070 & 0 & 323 & 3142 & 40,000 & 6141 & 920 \\
\hline MS & 36 & 15 & 15 & 579 & 0 & 24 & 242 & 123,317 & 6709 & 0 \\
\hline MT & 19 & 10 & 10 & 1531 & 0 & 15 & 152 & 0 & 291 & 0 \\
\hline $\mathrm{NC}$ & 69 & 31 & 30 & 436 & 0 & 975 & 9493 & 116,400 & 11,148 & 16,400 \\
\hline ND & 48 & 14 & 14 & 1002 & 0 & 27 & 257 & 0 & 0 & 800 \\
\hline $\mathrm{NE}$ & 80 & 31 & 30 & 1950 & 4885 & 286 & 2784 & 567 & 11,909 & 2400 \\
\hline $\mathrm{NH}$ & 18 & 8 & 8 & 4 & 0 & 0 & 4 & 0 & 139 & 6 \\
\hline NJ & 16 & 6 & 6 & 8 & 0 & 0 & 5 & 0 & 2030 & 24 \\
\hline NM & 261 & 51 & 50 & 549 & 183 & 0 & 3 & 0 & 0 & 0 \\
\hline NV & 25 & 12 & 12 & 250 & 0 & 0 & 5 & 0 & 0 & 0 \\
\hline NY & 670 & 302 & 295 & 80 & 0 & 7 & 65 & 350 & 3974 & 204 \\
\hline $\mathrm{OH}$ & 265 & 118 & 115 & 275 & 0 & 136 & 1320 & 7617 & 31,129 & 1760 \\
\hline VA & 119 & 58 & 57 & 671 & 0 & 30 & 303 & 44,150 & 3463 & 10,200 \\
\hline VT & 158 & 64 & 62 & 10 & 0 & 0 & 4 & 0 & 232 & 19 \\
\hline WA & 244 & 107 & 104 & 271 & 560 & 3 & 29 & 0 & 4836 & 0 \\
\hline WI & 1330 & 651 & 635 & 230 & 0 & 56 & 543 & 5467 & 4456 & 1600 \\
\hline WV & 17 & 5 & 5 & 193 & 0 & 1 & 7 & 15,217 & 1051 & 1640 \\
\hline WY & 5 & 1 & 1 & 825 & 0 & 15 & 140 & 0 & 12 & 0 \\
\hline U.S. & 9195 & 4146 & 4045 & 33,316 & 23,390 & 5208 & 50,659 & $1,376,955$ & 324,922 & 99,383 \\
\hline
\end{tabular}

PDeath is the change in monthly death rate from heat stress, and

EXP is the exponentiation function (i.e., e exponent the expression in parentheses).

The relationships between $\mathrm{DO}_{\text {Loss }}$, RcullRate, and $\mathrm{PR}$ were derived using a Markov chain Monte Carlo procedure (St-Pierre and Jones, 2001).

\section{Dairy Replacement Model}

Insufficient data were available to develop a model specific to growing dairy animals. We used the finishing beef cattle model and adjusted the parameters to reasonable targets of daily gain and DMI. Replacement animals under $1 \mathrm{yr}$ of age were modeled according to the following equations:

$$
\mathrm{DMI}_{\text {Loss }}=5.0 \times 0.032 \times \mathrm{THI}_{\text {Load }} / 100
$$


Table 3. Studies used to develop biological response functions to heat stress.

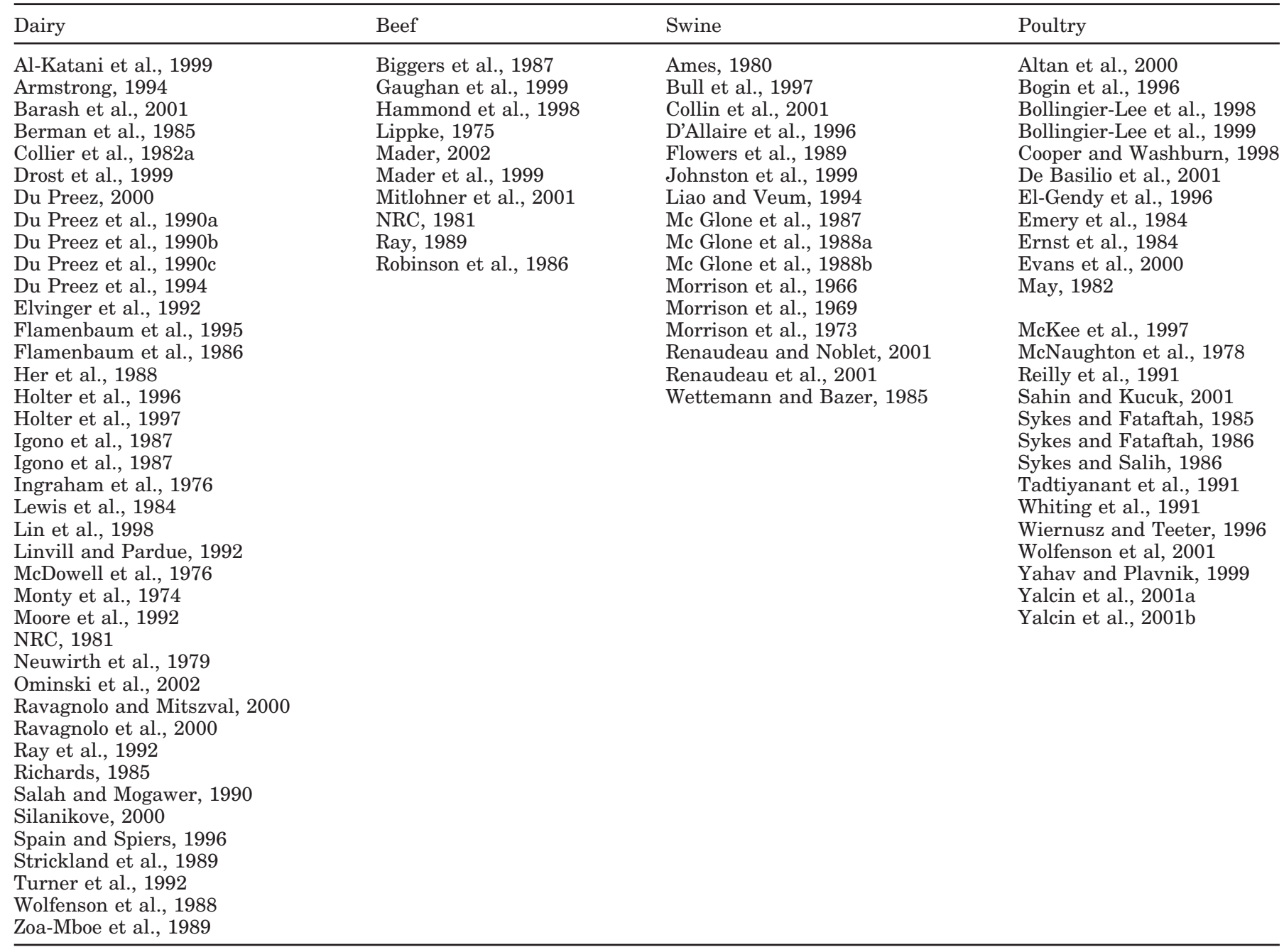

$$
\begin{aligned}
\text { Gain }_{\text {Loss }} & =0.90 \times 0.064 \times \mathrm{THI}_{\text {Load }} / 100 \\
\text { PDeath } & =0.0004275 \times \operatorname{EXP}\left(0.00981 \times \mathrm{THI}_{\text {Loadm }}\right)
\end{aligned}
$$

where

Gain $_{\text {Loss }}$ is the loss in BW gain (kilogram per animal per day).

Equations for replacement heifers over one year of age were:

$$
\begin{aligned}
\mathrm{DMI}_{\text {Loss }} & =10.0 \times 0.032 \times \mathrm{THI}_{\text {Load }} / 100 \\
\mathrm{Gain}_{\text {Loss }} & =1.0 \times 0.064 \times \mathrm{THI}_{\text {Load }} / 100 \\
\text { PDeath } & =0.0004275 \times \mathrm{EXP}\left(0.00981 \times \mathrm{THI}_{\text {Loadm }}\right)
\end{aligned}
$$

$\mathrm{THI}_{\text {Load }}$ and $\mathrm{THI}_{\text {Loadm }}$ are functions of $\mathrm{THI}_{\text {threshold, }}$ which was set at 77 for animals under a year of age and 72 for older replacement animals.

\section{Beef Cow Model}

Studies used to develop response functions in beef are reported in Table 3. Equations used to model the response of beef cows to heat stress were:

$$
\begin{aligned}
\mathrm{DMI}_{\text {Loss }}= & 0 \\
\mathrm{PR}= & 0.70-\left(0.0090 \times \mathrm{THI}_{\text {Loadm }}\right) \\
\mathrm{DO}_{\text {Loss }}= & 145.9-(149.0 \times \mathrm{PR})+\left(76.34 \times \mathrm{PR}^{2}\right)- \\
& 79 \\
\text { RCullRate }= & 0 \\
\text { PDeath }= & 0.0004275 \times \mathrm{EXP}\left(0.00981 \times \mathrm{THI}_{\text {Loadm }}\right)
\end{aligned}
$$

Although it is probable that DMI of range cattle drops when animals are heat stressed, published observations are lacking to quantify the process. Thus, we assumed this loss to be negligible. 


\section{Finishing Cattle Model}

The following set of equations were developed for this class of animals:

$$
\begin{aligned}
\mathrm{DMI}_{\text {Loss }} & =9.1 \times 0.032 \times \mathrm{THI}_{\text {Load }} / 100 \\
\text { Gain }_{\text {Loss }} & =1.36 \times 0.064 \times \mathrm{THI}_{\text {Load }} / 100 \\
\text { PDeath } & =0.0004275 \times \mathrm{EXP}\left(0.00981 \times \mathrm{THI}_{\text {Loadm }}\right) .
\end{aligned}
$$

\section{Sow Model}

Studies used to develop equations for sows and growfinish hogs are reported in Table 3. For sows, the following set of equations resulted:

$$
\begin{aligned}
\text { DMI }_{\text {Loss }} & =0 \\
\text { ARate } & =0.00227 \times \mathrm{THI}_{\text {Loadm }} \\
\text { DOLoss } & =37 \times \text { ARate } \\
\text { RCullRate } & =0 \\
\text { PDeath } & =0.000855 \times \operatorname{EXP}\left(0.00981 \times \mathrm{THI}_{\text {Loadm }}\right),
\end{aligned}
$$

where

$$
\text { ARate is the abortion rate. }
$$

Although sows reduce feed intake when heatstressed, this is done at the expense of BW loss that must be replenished later. Thus, there are no realized net savings in feed over a full reproductive cycle, which is why we set the value of $\mathrm{DMI}_{\mathrm{Loss}}$ to 0 . From a reproduction standpoint, we assumed that sows are not culled for reproductive failures due to heat stress. The cost of a prostaglandin injection to resume reproduction was added to each reproductive failure.

\section{Grow-Finish Hog Model}

Equations used for grow-finish hogs were:

$$
\begin{aligned}
\mathrm{DMI}_{\text {Loss }} & =0.00308 \times \mathrm{THI}_{\text {Load }} \\
\text { Gain }_{\text {Loss }} & =0.00154 \times \mathrm{THI}_{\text {Load }} \\
\text { PDeath } & =0.0004275 \times \mathrm{EXP}\left(0.00981 \times \mathrm{THI}_{\text {Loadm }}\right) .
\end{aligned}
$$

\section{Poultry-Broilers Model}

Studies used to develop response functions for all three poultry species are reported in Table 3 . For broiler chickens, the following equations were developed.

$$
\begin{aligned}
\mathrm{DMI}_{\text {Loss }} & =0.22 \times \mathrm{THI}_{\text {Load }} / 168 \\
\text { Gain }_{\text {Loss }} & =0.11 \times \mathrm{THI}_{\text {Load }} / 168 \\
\text { PDeath } & =0.0004275 \times \mathrm{EXP}\left(0.00981 \times \mathrm{THI}_{\text {Loadm }}\right) .
\end{aligned}
$$

\section{Poultry-Layers Model}

The following equations were used to model physical losses of laying hens:

$$
\begin{aligned}
\mathrm{DMI}_{\text {Loss }}= & 0.12 \times\left(0.0366 \times \mathrm{THI}_{\text {Load }}\right) / 100 \\
\mathrm{EGG}_{\text {Loss }}= & 0.048-\left(\left(0.8-\left(0.00034 \times \mathrm{THI}_{\text {Load }}\right)\right) \times(0.06\right. \\
& \left.-\left(0.0000123 \times \mathrm{THI}_{\text {Load }}\right)\right) \\
\text { PDeath }= & 0.0004275 \times \operatorname{EXP}\left(0.00981 \times \mathrm{THI}_{\text {Loadm }}\right),
\end{aligned}
$$

where

$\mathbf{E G G}_{\text {Loss }}$ is the loss in egg production (kilogram per hen per day).

Note that the equation for $\mathrm{EGG}_{\text {Loss }}$ incorporates the negative effects of heat stress on both the percent henday production and egg size. Production losses are converted to dozen egg equivalents assuming that a standard dozen of eggs weighs $0.72 \mathrm{~kg}$ (i.e., $1 \mathrm{egg}=0.06 \mathrm{~kg}$ ).

\section{Poultry-Turkeys Model}

Data on the effect of heat stress in growing turkeys are scarce. We used the model developed for broilers, substituting parameters in line with normal growth of turkeys at an average $4.5 \mathrm{~kg}$ of BW.

$$
\begin{aligned}
\mathrm{DMI}_{\text {Loss }} & =0.020 \times \mathrm{THI}_{\text {Load }} / 168 \\
\mathrm{GAIN}_{\text {Loss }} & =0.0085 \times \mathrm{THI}_{\text {Load }} / 168 \\
\operatorname{PDeath} & =0.0004275 \times \operatorname{EXP}\left(0.00981 \times \mathrm{THI}_{\text {Load }}\right)
\end{aligned}
$$

\section{Physical and Economic Inputs}

Table 1 reports $\mathrm{THI}_{\text {threshold }}$ assumptions used for each of the 10 animal classes. Because current selection for production reduces heat tolerance in dairy (Ravagnolo et al., 2000), we lowered the $\mathrm{THI}_{\text {threshold }}$ of dairy cows from the traditional value of 72 established many years ago to a value of 70 . Other values of $\mathrm{THI}_{\text {threshold }}$ were as reported or calculated from literature data.

Unit values for each of the five categories of losses are given for each animal class in Table 1. Values were chosen to represent average US costs over the last 5 yr. The price of some animal commodities (e.g., milk) varies appreciably over US regions and over time. The variation in output unit values was not factored in our model.

\section{Cooling Systems}

Equations presented so far are applicable to animals maintained in a system of minimal cooling. In confine- 
ment, such a system would rely on natural ventilation or mechanized ventilation where air exchange is limited to providing animals with adequate air exchange to maintain its chemical quality but without creating sufficient air movement around the animals to result in significant cooling effects. In dry lots, the equations implicitly assume that animals have access to shade because solar radiation is not factored in the response model.

Moderate heat abatement. The first intensity of heat abatement modeled was conceptualized as a system of fans or forced ventilation and was classified as "moderate". In dairy cows, literature data (Berman et al., 1985; Flamenbaum et al., 1986; Strickland et al., 1989; Means et al., 1992; Turner et al., 1992; Lin et al., 1998) were used to derive the effectiveness of moderate heat abatement, which was expressed as the decrease in apparent THI experienced by the animals. In our model, the actual THI is replaced by the apparent THI when one of the three levels of heat abatement is used. Figure 2 a depicts the effect of moderate heat abatement intensity on apparent THI as a function of temperature and relative humidity according to the following equation:

$$
\Delta \mathrm{THI}=-11.06+(0.25 \times \mathrm{T})+(0.02 \times \mathrm{H})
$$

where

$\Delta$ THI is the change in apparent THI $\mathbf{T}$ is ambient temperature $\left({ }^{\circ} \mathrm{C}\right)$, and $\mathbf{H}$ is ambient relative humidity (\%).

This equation was used across all animal types to estimate the physical effectiveness of a moderate heat abatement system. From a cost standpoint, one cooling unit was used per $50 \mathrm{~m}^{2}$ of housing or per $3800 \mathrm{~kg}$ of BW. The purchase cost per cooling unit was set at $\$ 250$, which was annualized at a rate of $15 \%$ to cover maintenance, depreciation, and interest costs. The sum of all fixed costs associated with the additional investments was labeled capital cost. Operating costs assumed an electrical consumption of $0.65 \mathrm{~kW} / \mathrm{h}$ of operation, and $\$ 0.09 / \mathrm{kW} \cdot \mathrm{h}$ of electricity.

High heat abatement. Conceptually, this intensity of heat abatement has the effectiveness of a combination of fans and sprinklers in dairy. For dairy cows, published data (Flamenbaum et al., 1986; Igono et al., 1987; Strickland et al., 1989; Means et al., 1992; Turner et al., 1992; Lin et al., 1998) were used to quantify the decline in apparent THI using the following equation:

$$
\Delta \mathrm{THI}=-17.6+(0.36 \times \mathrm{T})+(0.04 \mathrm{H})
$$

Figure $2 \mathrm{~b}$ shows the drop in apparent THI for a high heat abatement system. Capital costs for this system a

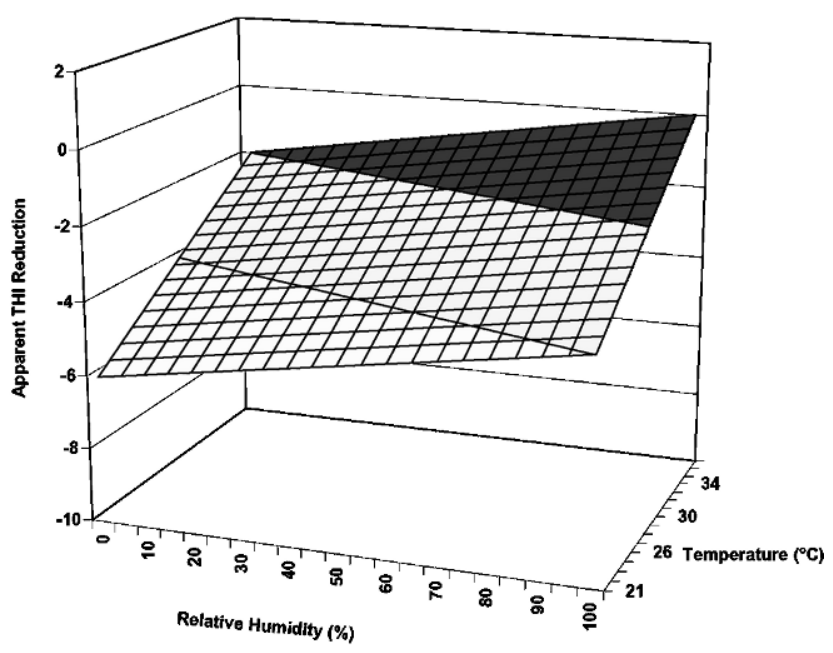

$\mathrm{b}$

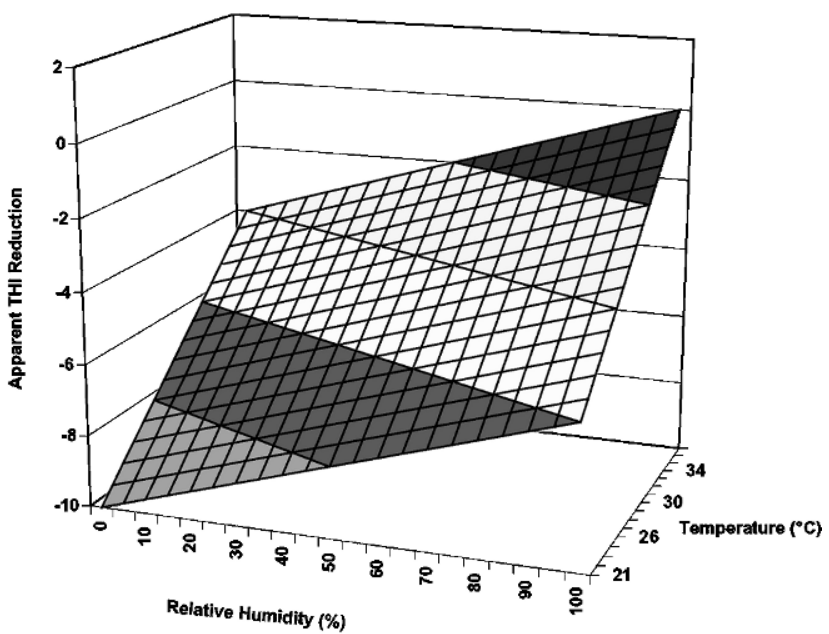

c

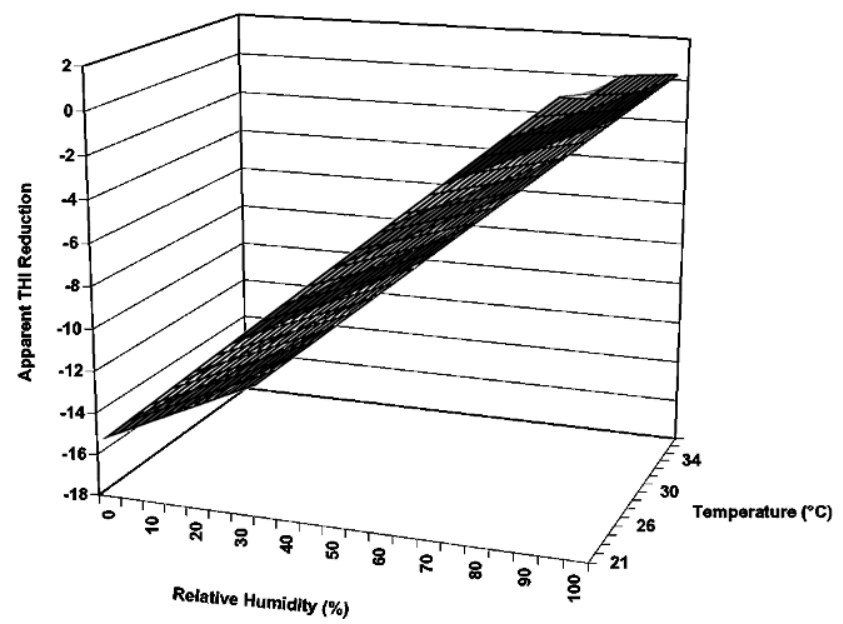

Figure 2. Apparent temperature-humidity index (THI) reduction as a function of temperature and relative humidity in a system providing a) moderate, b) high, and c) intense heat abatement intensity. 
were calculated as those of the moderate system plus $\$ 60$ of additional investments per $50 \mathrm{~m}^{2}$ of housing or per $3800 \mathrm{~kg}$ of $\mathrm{BW}$; these costs were annualized at a rate of $25 \%$ to cover depreciation, interest, and the additional maintenance. Operating costs were the same as those for the moderate system augmented by $\$ 0.01 / \mathrm{h}$ of operation.

Intense heat abatement. Conceptually, this intensity of heat abatement has the cooling properties of a high-pressure evaporative cooling system in dairy. Field data from a commercial manufacturer (Korral Kool, Inc., Mesa, AZ) were used to quantify the cooling effect of an intense heat abatement system. Evaporative cooling is the only commercially available system that actually decreases the actual THI as opposed to changing the apparent THI. The drop in apparent THI at various combinations of $\mathrm{T}$ and $\mathrm{H}$ is shown in Figure 2c based on the following equation:

$$
\Delta \mathrm{THI}=-11.7-(0.16 \times \mathrm{T})+(0.18 \times \mathrm{H})
$$

Capital costs were calculated based on additional investments of $\$ 6000$ per $120 \mathrm{~m}^{2}$ or per $8865 \mathrm{~kg}$ of BW, annualized at a rate of $15 \%$. Operating costs were calculated using a rate of $\$ 0.23 / \mathrm{h}$ of operation per unit.

\section{Simulation}

Monte Carlo techniques were used to simulate the variation of weather data across time. A variance-covariance matrix and a vector of means of minimum and maximum $\mathrm{T}$ and $\mathrm{H}$ were calculated for each month within each state. These were used to generate $30 \mathrm{~d}$ of weather data per month, assuming a multivariate normal distribution of all four variables using the algorithm of Fishman (1978). This process was iterated 1000 times for each month within each state and for each of the 10 animal classes and four heat abatement intensities.

\section{RESULTS AND DISCUSSION}

\section{Weather}

Mean weather data for the month of July are presented in Table 4 . The aggregation of weather data to the state level distorts the heat stress picture for a few states. In Texas, for example, the weather in July is typically hot and dry in the northwest panhandle but hot and humid in the area along the Gulf of Mexico. Although this aggregation may impact our assessment of the optimal cooling system for a given animal class in a few states, it probably has minor impact on the overall economic impact on a national basis.

Beyond the obvious general increase in THI from North to South, information in Table 4 demonstrates the need to account for $\mathrm{T}, \mathrm{H}$, and THI patterns beyond their simple daily averages. For example, Ohio and Montana have the same average maximum $\mathrm{T}$, but minimum $\mathrm{T}$ is $5.5^{\circ} \mathrm{C}$ less in MT. The average maximum THI in Idaho and Rhode Island are identical, but the average minimum THI is 10 units less in Idaho. High humidity compounds the effects of high temperatures. For example, although Utah and South Carolina have nearly the same average maximum temperature $\left(31.5^{\circ} \mathrm{C}\right)$, the $\mathrm{THI}_{\max }$ and the $\mathrm{THI}_{\min }$ are 7.1 and 13.8 units lower, respectively, in Utah.

The difference between the average minimum and maximum THI varies considerably across states. In general, the $\mathrm{THI}_{\text {spread }}$ is small in southeastern states and large in western states. This has a substantial impact on the magnitude and duration of heat stress on a given day. During an average July day in Florida, for example, a dairy cow would be constantly under heat stress conditions, whereas a cow in Arizona (the state with the highest mean maximum temperature in July) would be exposed to THI conditions under her $\mathrm{THI}_{\text {threshold }}$ for approximately $8 \mathrm{~h} / \mathrm{d}$.

\section{Impact of Heat Stress on Productivity Without Heat Abatement Systems}

Dairy cows. The impact of heat stress on the productivity of dairy cows in the absence of heat abatement is presented in Table 5. Reduction in milk production ranges between 68 and $2072 \mathrm{~kg} / \mathrm{cow}$ per year in Wyoming and Louisiana, respectively. The effect on reproduction varies considerably across states, with a low of 4.3 and 2.7 in Wyoming and a high of 57.7 and 88.0 in Louisiana for $\mathrm{DO}_{\text {Loss }}$ (days) and RCullRate (animals/1000 animals), respectively. Annual heat stress is summarized in terms of duration (hours per year) and extent (as a sum of $\mathrm{THI}_{\mathrm{Load}}$ per year). The $\mathrm{THI}_{\text {Load }}$ per hour of heat stress varies across states to a low of $4.4(2558 \div 581)$ and a high $8.0(25,597 \div 3185)$ units/h in Idaho and Texas, respectively, averaging $6.4 \mathrm{units} / \mathrm{h}$ across all states. Clearly, cows in Alabama, Florida, Louisiana, Mississippi, and Texas are severely affected both in duration and extent of heat stress in the absence of heat abatement. In Florida, for example, close to $50 \%$ of all annual hours are under temperature and humidity conditions resulting in heat stress. Nationally, the average dairy cow is exposed $14.1 \%$ of all annual hours to conditions of heat stress.

Dairy replacement. Tables 6 and 7 present the impact of heat stress on productivity of dairy replacements in the absence of heat abatement. The reduction in annual growth of young heifers varies across states with a low of 0.2 and a high of $7.9 \mathrm{~kg} / \mathrm{heifer}$ per year in Wyoming and Texas, respectively. In older heifers, reduction 
Table 4. Mean minima and maxima for temperature, relative humidity, and temperature-humidity index during the month of July in each of the 48 contiguous states.

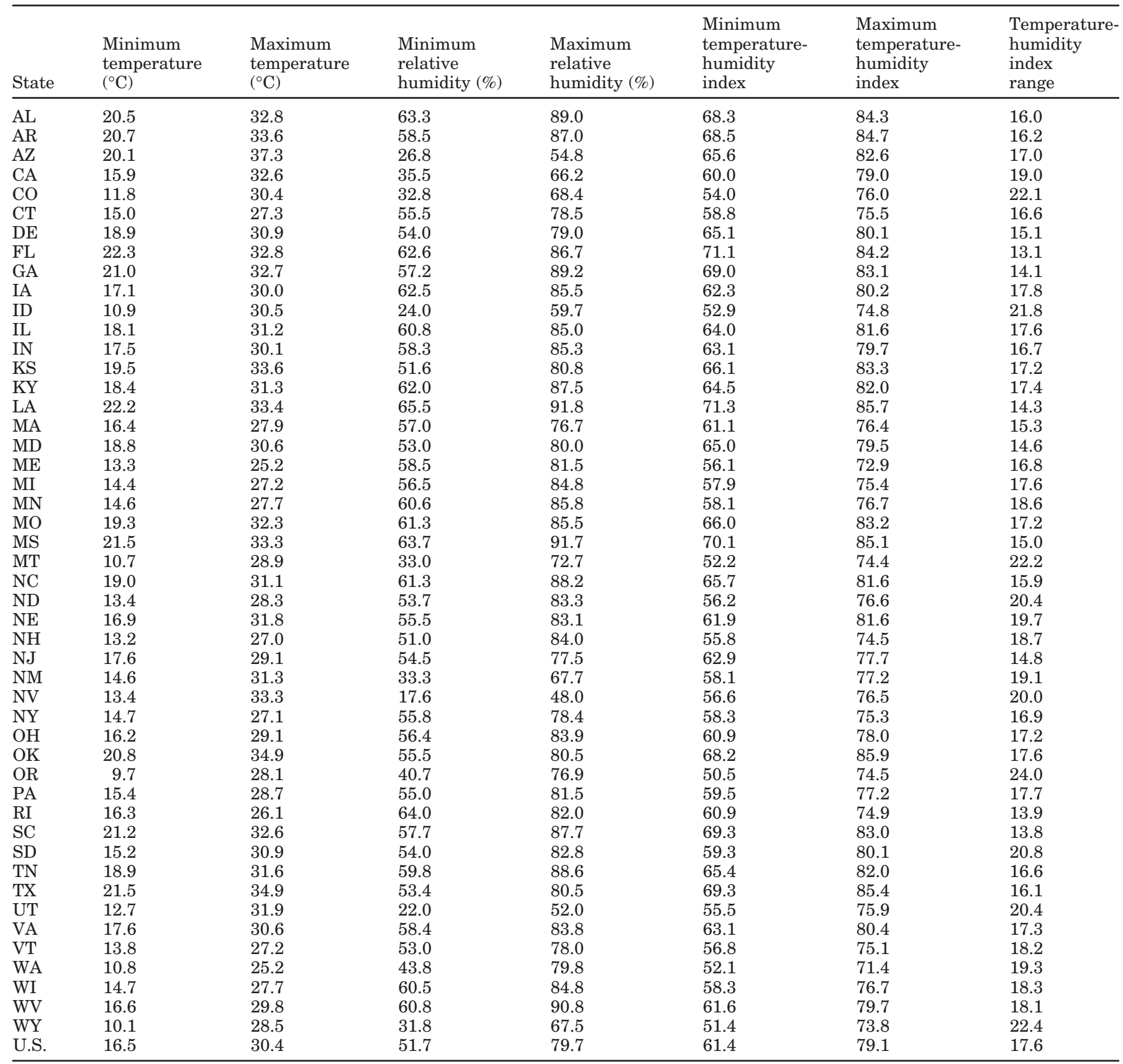

in annual growth is least in Idaho, Maine, Montana, and Wyoming and greatest in Louisiana at 1.0 and $17.4 \mathrm{~kg} /$ heifer per year, respectively. Overall, replacement heifers are much less impacted by heat stress than dairy cows. Younger heifers have a higher $\mathrm{THI}_{\text {threshold }}$, resulting in considerably fewer excess $\mathrm{THI}_{\mathrm{Load}}(2588$ vs. 9337) than dairy cows. Similar results are obtained with yearlings, although the differences with dairy cows are of lesser magnitude.
Beef cows and finishing cattle. The effect of heat stress on breeding beef cows without heat abatement is reported in Table 8. Overall, the magnitude of production losses is relatively small across all states. This is due to 1) the relatively high $\mathrm{THI}_{\text {threshold }}$ of beef cows, which is a consequence of their lower metabolic rate than dairy cows, and 2) breeding of beef cattle in the United States occurs primarily during the spring, a season of lesser heat stress. 
Table 5. Estimated annual production losses by dairy cows and duration and extent of heat stress periods under minimum heat abatement intensity.

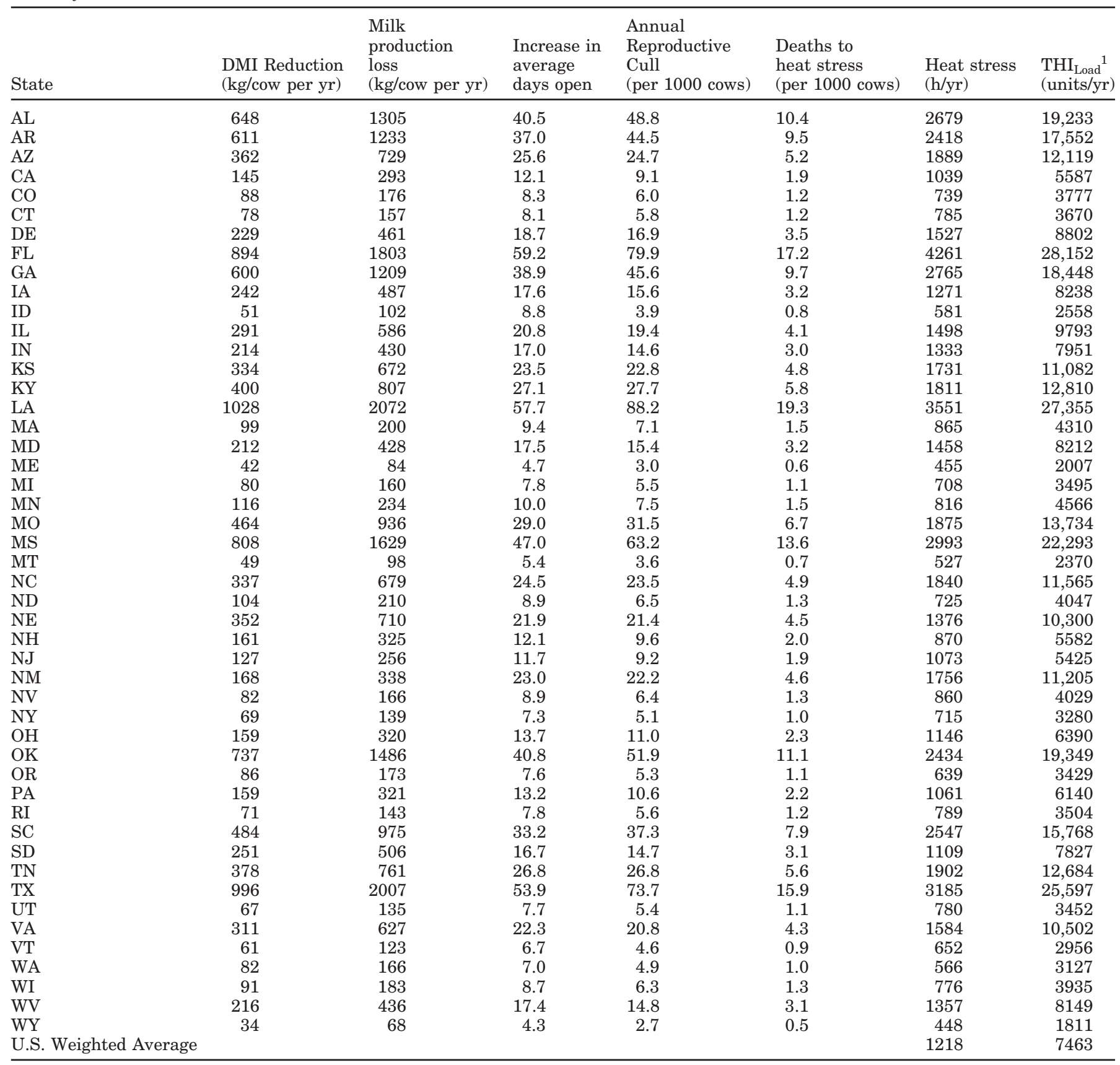

${ }^{1} \mathrm{THI}_{\mathrm{Load}}$ is the integral of the daily THI sine curve above $\mathrm{THI}_{\text {threshold }}$, which is the THI above which heat stress occurs.

The effects of heat stress without abatement on performance of finishing cattle are reported in Table 8. Most of US beef production occurs in the western part of the central plains (Table 2). Over $70 \%$ of all cattle finished in the United States are fed in Texas, Kansas, and Nebraska, which are three states with $\mathrm{THI}_{\mathrm{Load}}$ values above the average of other beef-producing states. With the exception of Texas and Oklahoma, the estimated annual
Gain $_{\text {Loss }}$ is less than $10 \mathrm{~kg} / \mathrm{yr}$, which is equivalent to seven additional days in the feedlot assuming a daily gain of $1.6 \mathrm{~kg} / \mathrm{animal}$.

Swine. Without any heat abatement, sow productivity is severely affected by heat stress in many states, some of these states being important in pork production (Table 9). In Texas, for example, an estimated 18.8 additional days open per sow would result from unabated heat 
Table 6. Estimated annual production losses by dairy replacement heifers from birth to 1 yr and duration and extent of heat stress periods under minimum heat abatement intensity.

\begin{tabular}{|c|c|c|c|c|c|}
\hline State & $\begin{array}{l}\text { DMI Reduction } \\
\text { (kg/heifer per yr) }\end{array}$ & $\begin{array}{l}\text { Growth loss } \\
\text { (kg/heifer per yr) }\end{array}$ & $\begin{array}{l}\text { Deaths to } \\
\text { heat stress } \\
\text { (per 1000) }\end{array}$ & $\begin{array}{l}\text { Heat stress } \\
(\mathrm{h} / \mathrm{yr})\end{array}$ & $\begin{array}{l}\mathrm{THI}_{\text {Load }}{ }^{1} \\
\text { (units/yr) }\end{array}$ \\
\hline $\mathrm{AL}$ & 17.0 & 5.1 & 1.0 & 1234 & 5926 \\
\hline $\mathrm{AR}$ & 16.0 & 4.8 & 1.0 & 1102 & 5589 \\
\hline $\mathrm{AZ}$ & 9.4 & 2.8 & 0.5 & 734 & 3276 \\
\hline CA & 3.6 & 1.1 & 0.2 & 307 & 1248 \\
\hline $\mathrm{CO}$ & 2.1 & 0.6 & 0.1 & 203 & 716 \\
\hline CT & 1.6 & 0.5 & 0.1 & 186 & 565 \\
\hline $\mathrm{DE}$ & 5.4 & 1.6 & 0.3 & 523 & 1895 \\
\hline FL & 21.0 & 6.3 & 1.3 & 1789 & 7346 \\
\hline GA & 14.8 & 4.4 & 0.9 & 1155 & 5172 \\
\hline IA & 6.4 & 1.9 & 0.3 & 498 & 2221 \\
\hline ID & 1.0 & 0.3 & 0.1 & 122 & 350 \\
\hline IL & 7.6 & 2.3 & 0.4 & 597 & 2648 \\
\hline IN & 5.4 & 1.6 & 0.3 & 475 & 1870 \\
\hline KS & 8.5 & 2.6 & 0.5 & 673 & 2984 \\
\hline $\mathrm{KY}$ & 10.8 & 3.3 & 0.6 & 812 & 3784 \\
\hline LA & 26.2 & 7.9 & 1.8 & 1735 & 9146 \\
\hline MA & 2.2 & 0.7 & 0.1 & 228 & 768 \\
\hline MD & 5.0 & 1.5 & 0.3 & 478 & 1746 \\
\hline $\mathrm{ME}$ & 0.9 & 0.3 & 0.0 & 95 & 299 \\
\hline MI & 1.8 & 0.5 & 0.1 & 183 & 621 \\
\hline MN & 2.9 & 0.9 & 0.1 & 260 & 1004 \\
\hline MO & 12.5 & 3.8 & 0.7 & 853 & 4360 \\
\hline MS & 20.8 & 6.2 & 1.3 & 1423 & 7261 \\
\hline MT & 1.0 & 0.3 & 0.0 & 115 & 350 \\
\hline $\mathrm{NC}$ & 8.6 & 2.6 & 0.5 & 701 & 2985 \\
\hline ND & 2.7 & 0.8 & 0.1 & 230 & 929 \\
\hline NE & 9.8 & 3.0 & 0.6 & 631 & 3440 \\
\hline $\mathrm{NH}$ & 4.4 & 1.3 & 0.2 & 334 & 1530 \\
\hline NJ & 2.8 & 0.9 & 0.1 & 293 & 989 \\
\hline NM & 8.4 & 4.2 & 0.9 & 998 & 4789 \\
\hline NV & 1.6 & 0.5 & 0.1 & 203 & 573 \\
\hline NY & 1.4 & 0.4 & 0.1 & 162 & 492 \\
\hline $\mathrm{OH}$ & 3.8 & 1.1 & 0.2 & 367 & 1330 \\
\hline OK & 19.9 & 6.0 & 1.3 & 1206 & 6965 \\
\hline OR & 2.1 & 0.6 & 0.1 & 186 & 745 \\
\hline PA & 4.0 & 1.2 & 0.2 & 357 & 1382 \\
\hline RI & 1.3 & 0.4 & 0.1 & 165 & 453 \\
\hline $\mathrm{SC}$ & 11.4 & 3.4 & 0.6 & 963 & 3980 \\
\hline SD & 7.0 & 2.1 & 0.4 & 476 & 2460 \\
\hline $\mathrm{TN}$ & 9.9 & 3.0 & 0.6 & 800 & 3452 \\
\hline TX & 26.5 & 7.9 & 1.7 & 1605 & 9246 \\
\hline UT & 1.3 & 0.4 & 0.1 & 165 & 441 \\
\hline VA & 8.2 & 2.5 & 0.5 & 649 & 2880 \\
\hline VT & 1.3 & 0.4 & 0.1 & 145 & 436 \\
\hline WA & 2.1 & 0.6 & 0.1 & 173 & 745 \\
\hline WI & 2.1 & 0.6 & 0.1 & 209 & 716 \\
\hline WV & 5.4 & 1.6 & 0.3 & 487 & 1897 \\
\hline WY & 0.6 & 0.2 & 0.0 & 79 & 216 \\
\hline \multicolumn{4}{|c|}{ U.S. Weighted Average } & 472 & 1010 \\
\hline
\end{tabular}

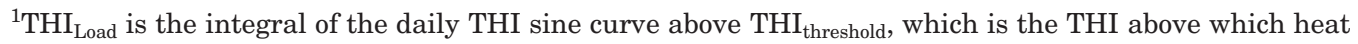
stress occurs.

stress on a yearly basis. The two states with the greatest number of farrowings per year, North Carolina and Iowa, would incur losses of 7.2 and 5.2 additional days open per sow on a yearly basis.

Loss of growth in grow-finish hogs from unabated heat stress is evident in those states with appreciable $\mathrm{THI}_{\mathrm{Load}}$, ranging from negligible in Wyoming to $7.2 \mathrm{~kg} / \mathrm{animal}$ per year in Louisiana (Table 9). The two largest hog- producing states, North Carolina and Iowa, have heat stress durations and extents that are somewhat close to the national average, resulting in Gain Loss $_{\text {of }} 2.9$ and 2.0 $\mathrm{kg} / \mathrm{animal}$ per year.

Poultry. Broiler performance is not affected markedly across all states even in the absence of heat abatement (Table 10). The Gain Loss $_{\text {per }} 1000$ birds is in all instances less than $0.5 \%$ of the total weight of bird produced. This 
Table 7. Estimated annual production losses by dairy replacement heifers from 1 to 2 yr and duration and extent of heat stress periods under minimum heat abatement intensity.

\begin{tabular}{|c|c|c|c|c|c|}
\hline State & $\begin{array}{l}\text { DMI Reduction } \\
\text { (kg/heifer per yr) }\end{array}$ & $\begin{array}{l}\text { Growth loss } \\
\text { (kg/heifer per yr) }\end{array}$ & $\begin{array}{l}\text { Deaths to } \\
\text { heat stress } \\
\text { (per 1000) }\end{array}$ & $\begin{array}{l}\text { Heat stress } \\
(\mathrm{h} / \mathrm{yr})\end{array}$ & $\begin{array}{l}\text { THI }_{\text {Load }}{ }^{1} \\
\text { (units/yr }\end{array}$ \\
\hline $\mathrm{AL}$ & 41.1 & 12.3 & 3.3 & 2195 & 14,361 \\
\hline $\mathrm{AR}$ & 37.7 & 11.3 & 3.0 & 1979 & 13,184 \\
\hline $\mathrm{AZ}$ & 25.1 & 7.5 & 1.7 & 1502 & 8757 \\
\hline CA & 10.9 & 3.3 & 0.6 & 765 & 3803 \\
\hline $\mathrm{CO}$ & 7.1 & 2.1 & 0.4 & 546 & 2493 \\
\hline CT & 6.7 & 2.0 & 0.4 & 566 & 2331 \\
\hline DE & 17.4 & 5.2 & 1.1 & 1196 & 6087 \\
\hline FL & 58.2 & 17.5 & 5.0 & 3519 & 20,343 \\
\hline GA & 38.5 & 11.6 & 3.0 & 2214 & 13,456 \\
\hline IA & 16.9 & 5.1 & 1.1 & 1015 & 5912 \\
\hline ID & 4.5 & 1.3 & 0.2 & 405 & 1560 \\
\hline IL & 20.3 & 6.1 & 1.3 & 1203 & 7088 \\
\hline IN & 16.1 & 4.8 & 1.0 & 1052 & 5606 \\
\hline KS & 22.9 & 6.9 & 1.5 & 1373 & 7983 \\
\hline $\mathrm{KY}$ & 27.1 & 8.1 & 1.9 & 1492 & 9467 \\
\hline LA & 59.5 & 17.9 & 5.9 & 2989 & 20,792 \\
\hline MA & 8.1 & 2.4 & 0.4 & 634 & 2817 \\
\hline MD & 16.2 & 4.8 & 1.0 & 1127 & 5654 \\
\hline $\mathrm{ME}$ & 3.5 & 1.1 & 0.2 & 311 & 1235 \\
\hline MI & 6.6 & 2.0 & 0.4 & 519 & 2305 \\
\hline MN & 8.9 & 2.7 & 0.5 & 622 & 3118 \\
\hline MO & 29.5 & 8.8 & 2.2 & 1541 & 10,286 \\
\hline MS & 48.2 & 14.5 & 4.3 & 2469 & 16,848 \\
\hline MT & 4.2 & 1.3 & 0.2 & 369 & 1481 \\
\hline $\mathrm{NC}$ & 23.7 & 7.1 & 1.6 & 1458 & 8265 \\
\hline ND & 8.0 & 2.4 & 0.4 & 550 & 2803 \\
\hline $\mathrm{NE}$ & 22.4 & 6.7 & 1.5 & 1136 & 7806 \\
\hline $\mathrm{NH}$ & 11.5 & 3.4 & 0.7 & 689 & 4011 \\
\hline NJ & 10.2 & 3.1 & 0.6 & 793 & 3564 \\
\hline NM & 22.6 & 6.8 & 1.4 & 1412 & 8025 \\
\hline NV & 7.3 & 2.2 & 0.4 & 630 & 2561 \\
\hline NY & 5.9 & 1.8 & 0.3 & 506 & 2060 \\
\hline $\mathrm{OH}$ & 12.6 & 3.8 & 0.7 & 887 & 4391 \\
\hline OK & 42.8 & 12.8 & 3.6 & 2027 & 14,940 \\
\hline OR & 6.7 & 2.0 & 0.4 & 472 & 2332 \\
\hline PA & 12.2 & 3.7 & 0.7 & 823 & 4254 \\
\hline RI & 6.1 & 1.8 & 0.3 & 553 & 2140 \\
\hline $\mathrm{SC}$ & 32.2 & 9.7 & 2.4 & 2002 & 11,255 \\
\hline SD & 16.6 & 5.0 & 1.0 & 900 & 5805 \\
\hline $\mathrm{TN}$ & 26.5 & 7.9 & 1.8 & 1547 & 9238 \\
\hline TX & 56.6 & 17.0 & 5.1 & 2652 & 19,758 \\
\hline UT & 6.1 & 1.8 & 0.3 & 557 & 2117 \\
\hline VA & 21.8 & 6.6 & 1.4 & 1283 & 7629 \\
\hline VT & 5.3 & 1.6 & 0.3 & 462 & 1853 \\
\hline WA & 6.2 & 1.8 & 0.3 & 418 & 2153 \\
\hline WI & 7.4 & 2.2 & 0.4 & 570 & 2569 \\
\hline WV & 16.4 & 4.9 & 1.0 & 1074 & 5719 \\
\hline WY & 3.1 & 0.9 & 0.2 & 301 & 1080 \\
\hline U.S. & & & & 868 & 4717 \\
\hline
\end{tabular}

${ }^{1} \mathrm{THI}_{\mathrm{Load}}$ is the integral of the daily THI sine curve above $\mathrm{THI}_{\text {threshold, which is the THI above which heat }}$ stress occurs.

is simply because the duration and extent of heat stress in broilers is relatively low across all states due to a high $\mathrm{THI}_{\text {threshold }}$ in broilers.

Productivity of layers is severely impacted by heat stress in the absence of heat abatement (Table 11).) Layers produce approximately 25,000 dozen of standard eggs $(60 \mathrm{~g})$ per 1000 birds per year. Thus, the EGG $\mathrm{ELoss}_{\text {in }}$ Florida, for example, amounts to $7.3 \%$ of total potential yearly production. The range in loss of productivity is predictably large, with the least being 118 and the greatest 1807 dozen of standard eggs lost per 1000 birds per year in New York and Florida, respectively.

Changes in turkey productivity from unabated heat stress vary substantially across states (Table 12). Growth loss is minimum in Vermont and maximum in Texas, at 6 and $153 \mathrm{~kg}$ of Gain Loss $_{\text {per }} 1000$ birds per year, 
Table 8. Estimated annual production losses by beef cows and finishing cattle and duration and extent of heat stress periods under minimum heat abatement intensity.

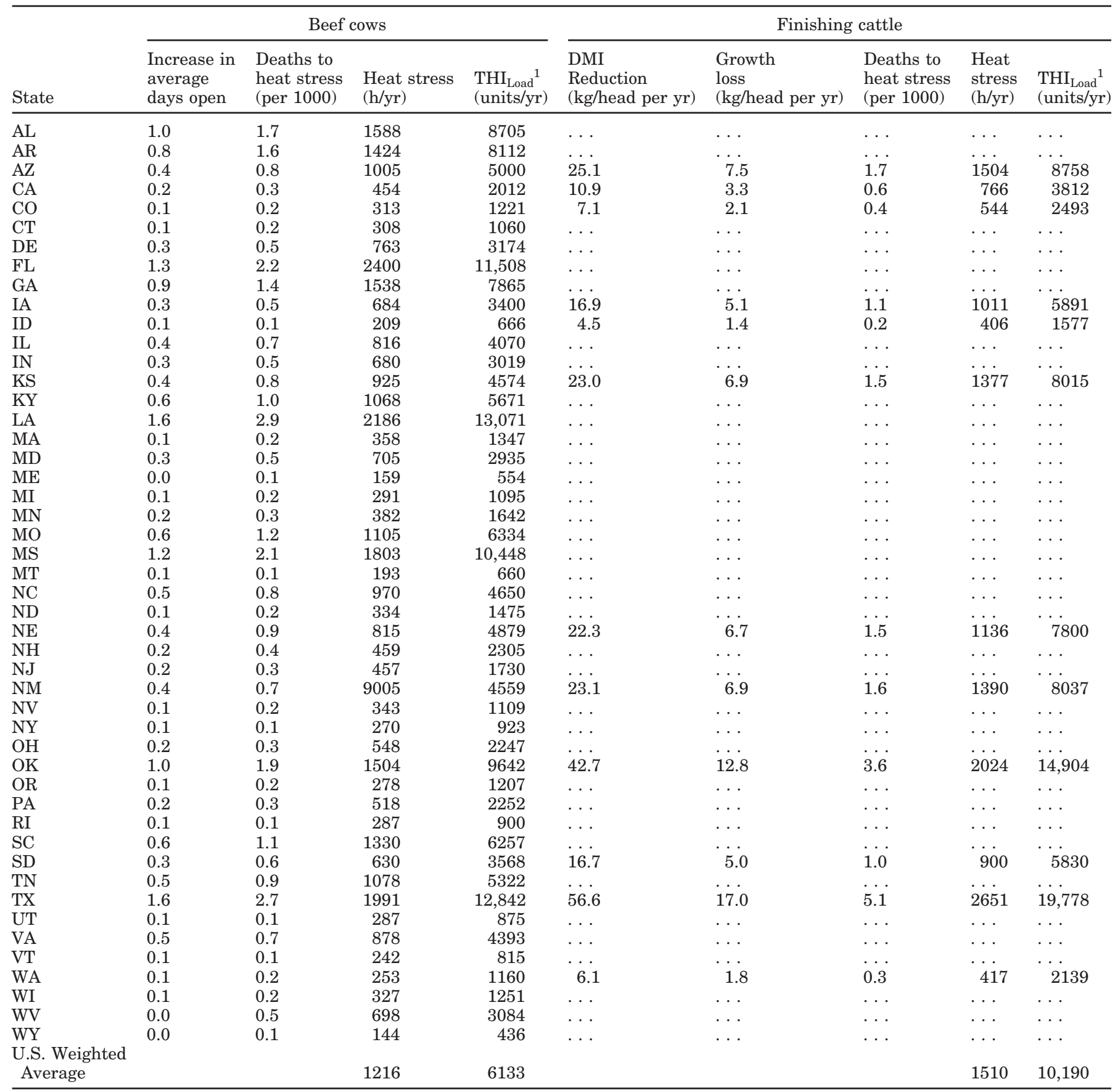

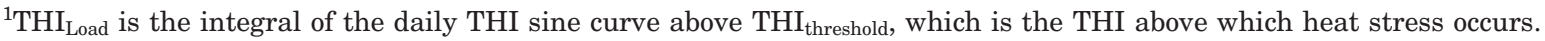

respectively. Relative to total growth, however, Gain Loss $_{1}$ from heat stress represents less than $1.5 \%$ of annual turkey production of approximately $10,000 \mathrm{~kg}$ per 1000 birds.

\section{Optimal Cooling and Economic Losses}

Optimal abatement systems and their associated total economic losses are presented for the three dairy animal classes in Table 13. Optimality of heat abatement was defined as minimum total economic losses, i.e., the greatest gain in revenues from heat abatement after subtracting the costs in that heat abatement system. Specifically, it is the least sum of $\mathrm{DMI}_{\text {Loss }}, \mathrm{Milk}_{\mathrm{Loss}}$, Gain ${ }_{\mathrm{Loss}}$, $\mathrm{EGG}_{\text {Loss }}, \mathrm{DO}_{\text {Loss }}$, RCullRate, and PDeath summed over all animals within an animal class in a given state and converted to dollar losses, plus the sum of capital and 
Table 9. Estimated annual production losses by sows and grow-finish hogs and duration and extent of heat stress periods under minimum heat abatement intensity.

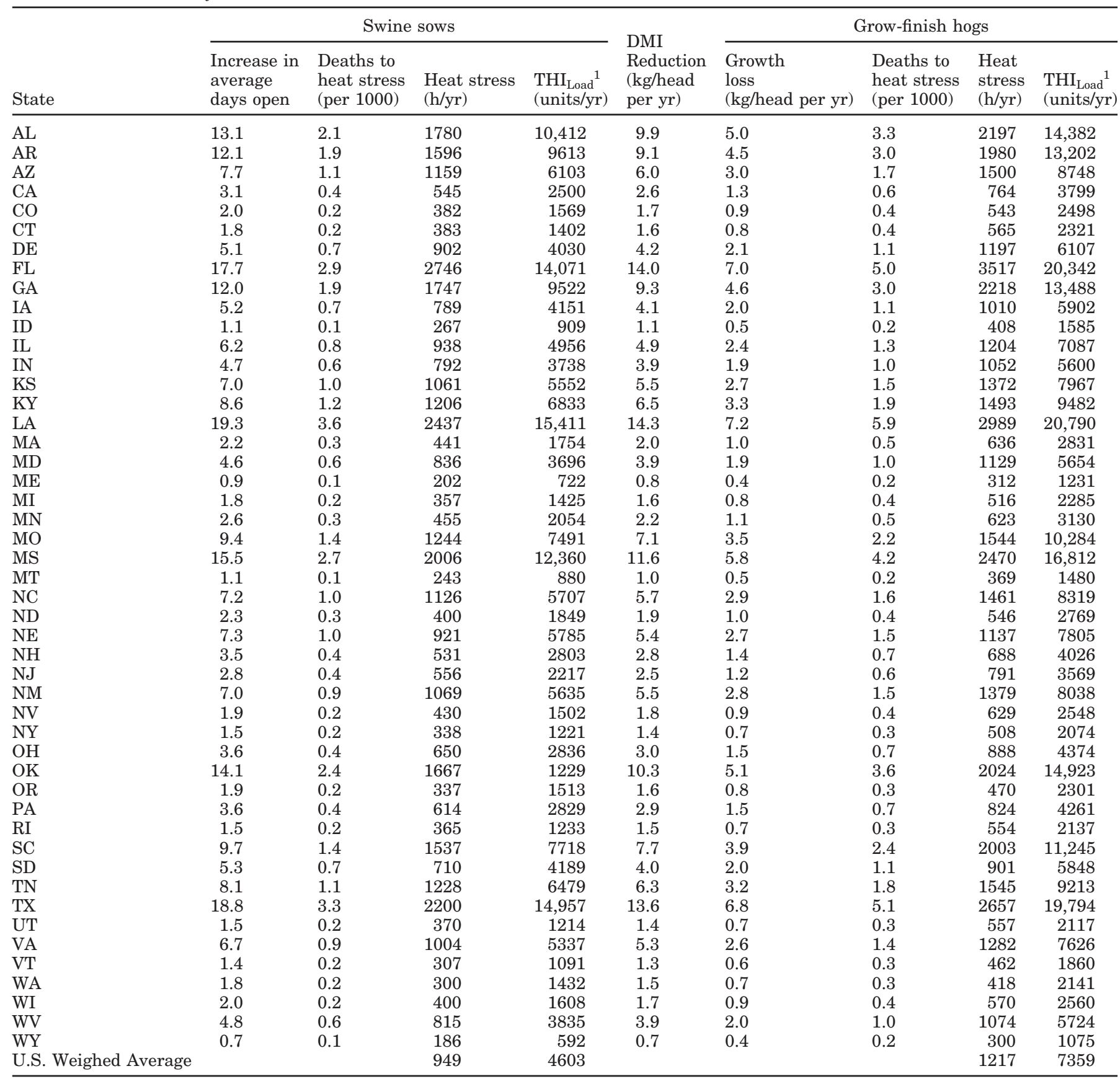

${ }^{1} \mathrm{THI}_{\mathrm{Load}}$ is the integral of the daily $\mathrm{THI}$ sine curve above $\mathrm{THI}_{\text {threshold, }}$ which is the $\mathrm{THI}$ above which heat stress occurs.

operating costs of a given heat abatement system for that given animal class in that given state. This optimality criterion is not to be confused with maximum reduction in production losses, which, in most instances, would result from the intensive heat abatement. For example, an intensive heat abatement system would reduce California Milk $_{\text {Loss }}$ more than a high abatement system (5 vs. $154 \mathrm{~kg} / \mathrm{cow}$ per year), but the total economic value of this additional reduction plus the net effect on $\mathrm{DMI}_{\mathrm{Loss}}$, $\mathrm{DO}_{\text {Loss }}$, RcullRate, and PDeath is less than the additional $\$ 86.7$ million of annual capital costs and $\$ 8.0$ million of annual operating costs required by the intensive system (data not shown).

Results show that for dairy cows some form of heat abatement is economically justified across all states, with an optimum intensity ranging from high to inten- 
Table 10. Estimated annual production losses by broilers and duration and extent of heat stress periods under minimum heat abatement intensity.

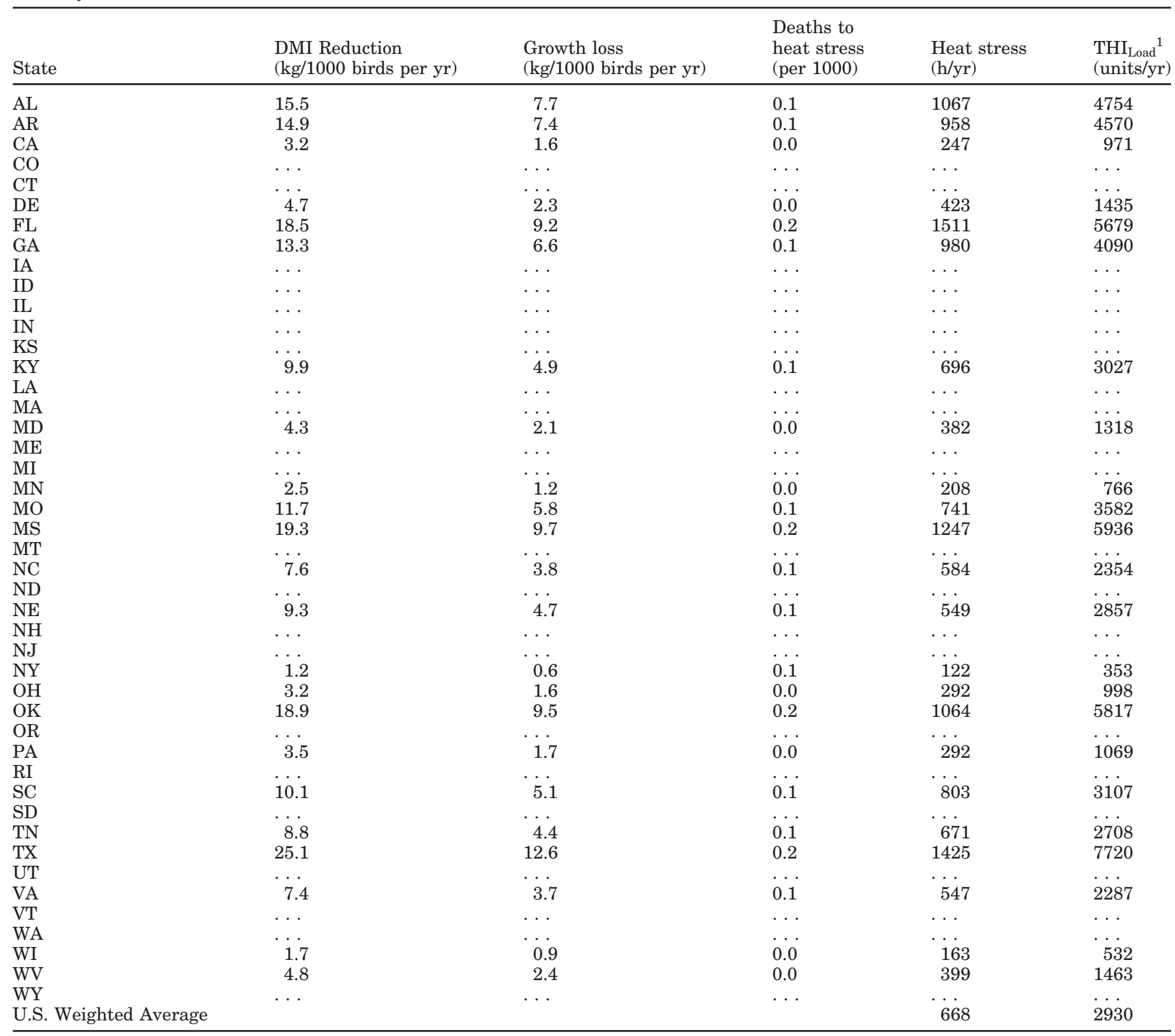

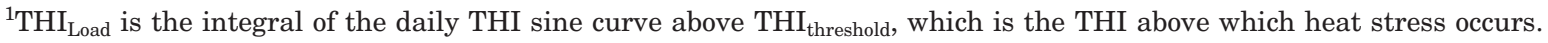

sive. Total economic losses vary tremendously across states due to differences in heat stress magnitude but also to the size of the industry in each state. Heat stress losses in replacement heifers, however, do not justify any mechanical heat abatement in any of the states. The combined losses from dairy cows and replacement animals are greatest for Texas, California, and Wisconsin. On a dairy cow basis, losses are greatest in Texas and Florida (383 and 337 \$/cow per year, respectively, data not shown). On a national basis, optimal heat abatement intensity reduces total economic losses to the dairy industry from $\$ 1507$ to $\$ 897$ million per year. Actual losses are bounded by these two values. The exact value of actual losses is dependent on the proportion of producers who have adopted the optimum level of heat abatement intensity.

In beef production, losses in productivity do not justify any heat abatement in any of the states for both beef cows and finishing cattle (Table 14). These results are not surprising, considering the extensive nature of beef cow production. On a national basis, heat stress results in $\$ 87.0$ million in total losses to the beef breeding herd, 
Table 11. Estimated annual production losses by layers and duration and extent of heat stress periods under minimum heat abatement intensity.

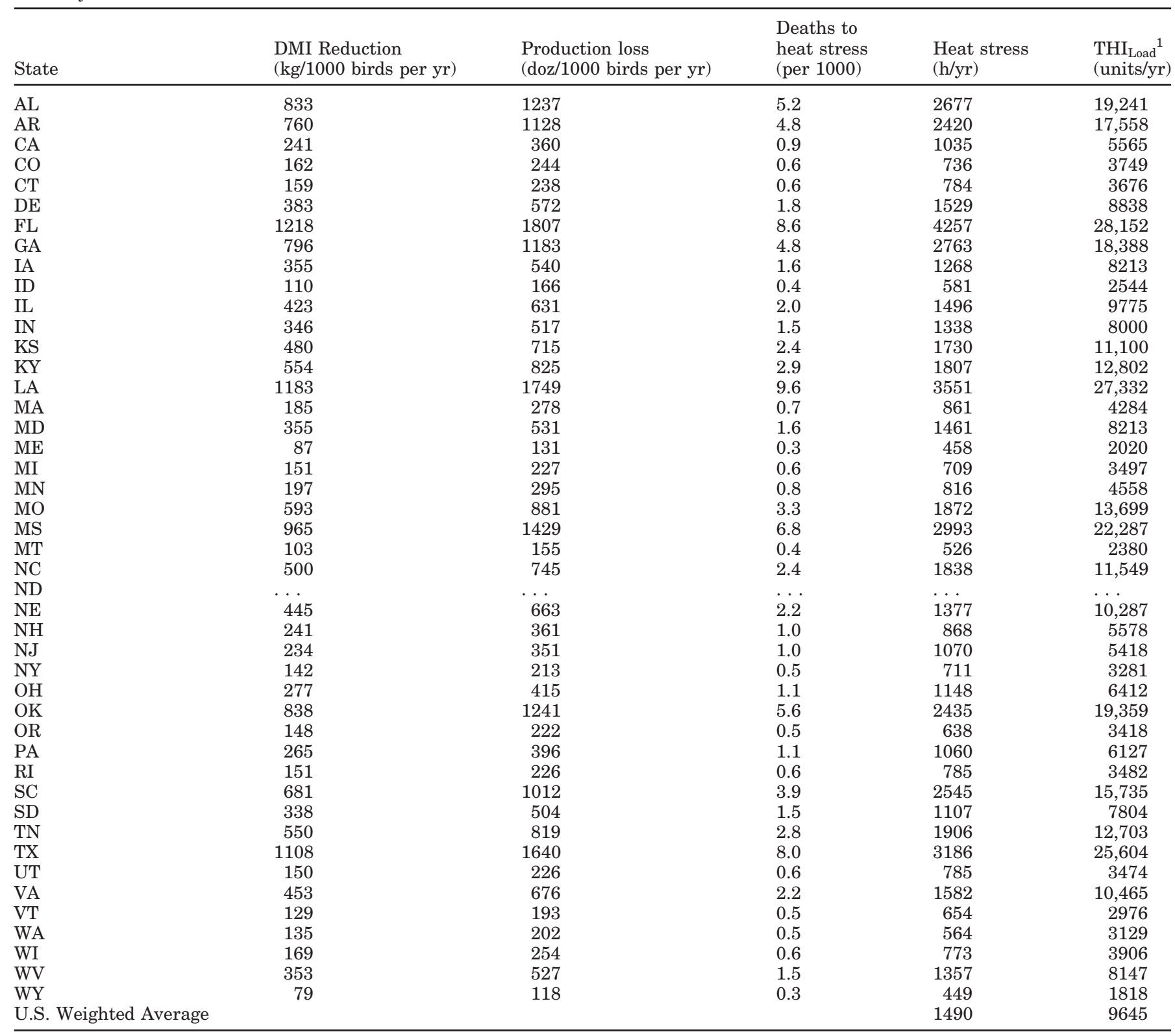

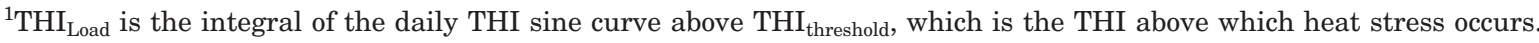

which translates to a small $\$ 2.60 /$ cow per year. Even in Texas, a state with significant heat stress and $\$ 33.2$ million in annual losses, the amount of loss per cow is estimated at $\$ 6.07 / \mathrm{cow}$ per year or less than $1.5 \%$ of annual gross income per cow (data not shown). The failure of any heat abatement intensity to be justified economically in finishing cattle is more surprising, considering the large economic cost estimated at $\$ 282$ million per year nationally. This figure translates to $\$ 12 /$ animal per year on a national basis, or approximately 1.5\% of gross income per animal (data not shown). Other advan- tages associated with the current major beef-producing states, such as lower feed costs, probably far outweigh the economic loss from heat stress. Additionally, beef producers can practice low input cooling strategies, such as ground wetting, that are very low cost and have been shown to be effective at reducing heat stress (Mader, 2002).

In swine, optimum sow production requires minimum or high heat abatement intensity (Table 14). Intensive heat abatement is optimal for the two largest sow-producing states, North Carolina and Iowa. Although opti- 
Table 12. Estimated annual production losses by turkeys and duration and extent of heat stress periods under minimum heat abatement intensity.

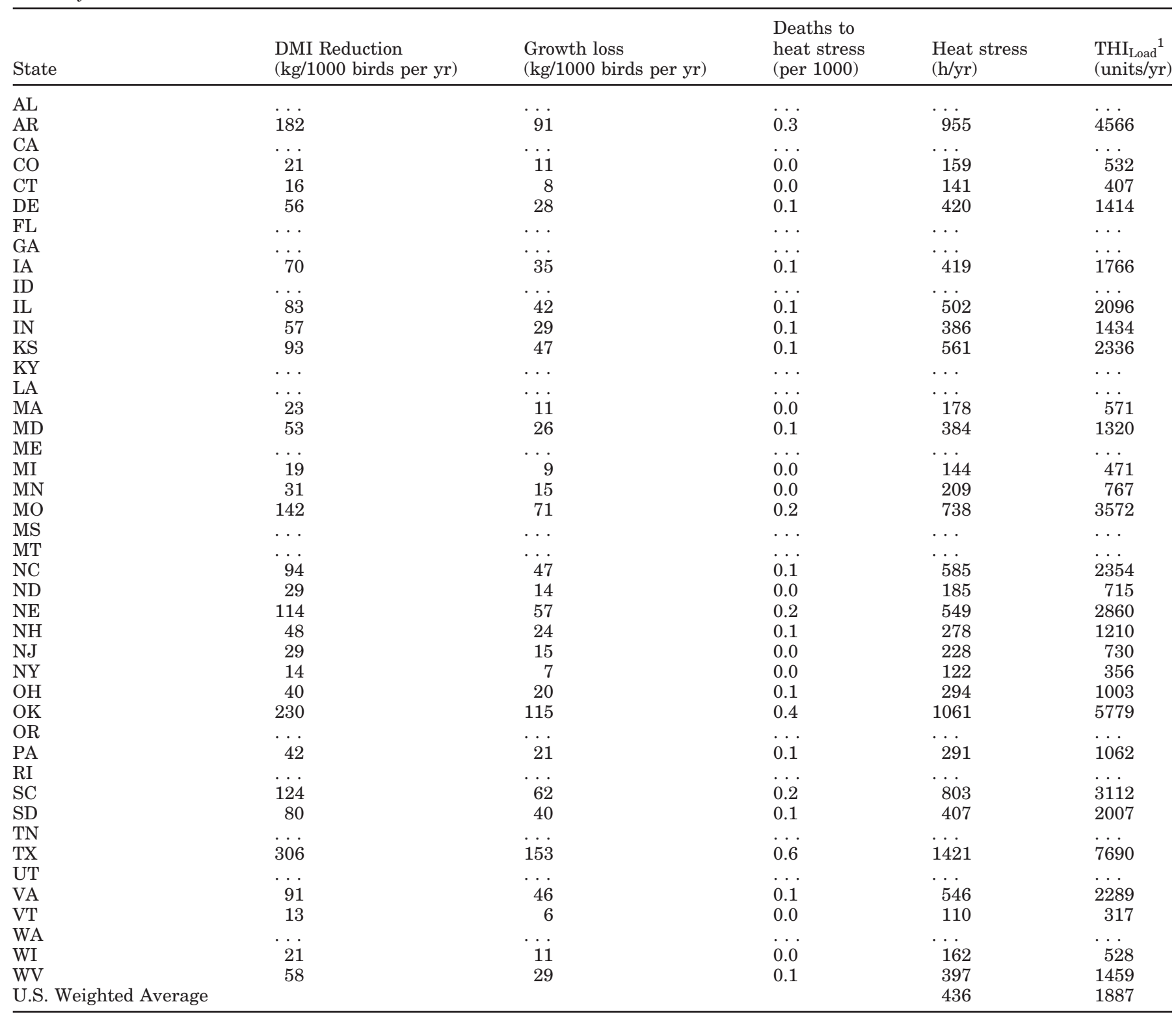

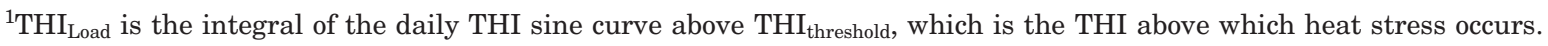

mal heat abatement does improve animal performance, the economic loss due to heat stress is not reduced considerably: $\$ 97$ vs. $\$ 113$ million per year nationally. Our model of losses in sows only accounted for losses in the form of additional days open in sows. The effect of heat stress on litter weight is not well defined, and young piglets seem to exhibit considerable compensatory gains in the 2 wk postweaning (Renaudeau and Noblet, 2001; Renaudeau et al., 2001). Additional data are needed in this area because a negative impact on the weight of piglets would increase the estimated losses to heat stress in sows considerably.
The economic losses in growing-finishing pigs are noticeably more than in sows (Table 14). Heat abatement would optimally be required in North Carolina but not in Iowa. The economic effectiveness of heat abatement is very small in grow-finish hogs. Essentially, the gains in productivity are nearly all negated by the additional capital and operating costs. Nationally, total economic losses in grow-finish pigs are estimated at $\$ 202$ million per year. Combined with sow production, annual losses to the swine industry are estimated at $\$ 299$ to $\$ 316$ million, depending on the proportion of the production achieved under optimal heat abatement intensity. 
Table 13. Optimal heat abatement intensity and total annual economic losses from heat stress in dairy.

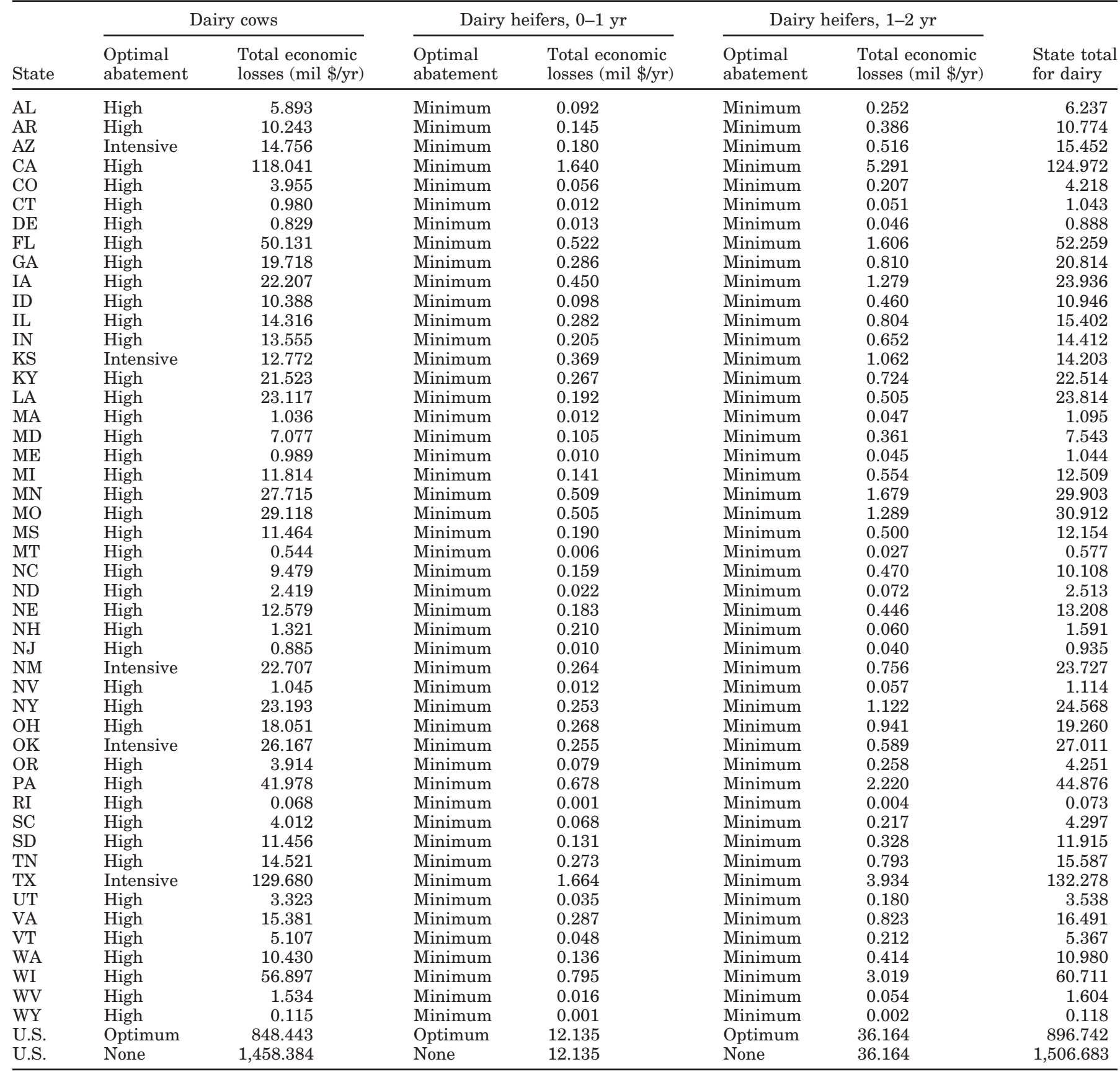

In poultry, economic losses in broiler production never justify the additional cost of heat abatement (Table 15). Nationally, the annual total economic losses are estimated at $\$ 51.8$ million, a very small amount in an industry that generates an estimated $\$ 20$ to $\$ 25$ billion of gross revenue per year.

The economic picture of losses to heat stress is quite different for layers (Table 15). High heat abatement intensity is economically optimal in all states. Optimum heat abatement reduces annual total economic losses from $\$ 98.1$ to $\$ 61.4$ million.

In turkey production, total annual losses are estimated at $\$ 14.4$ million nationally, with little effect of heat abatement intensity. This loss seems insignificant in an industry that generates approximately $\$ 4$ billion in gross returns per year.

Across all animal classes, the estimated national annual losses to heat stress are estimated at $\$ 2.4$ billion 
Table 14. Optimal heat abatement intensity and total annual economic losses from heat stress in beef and swine.

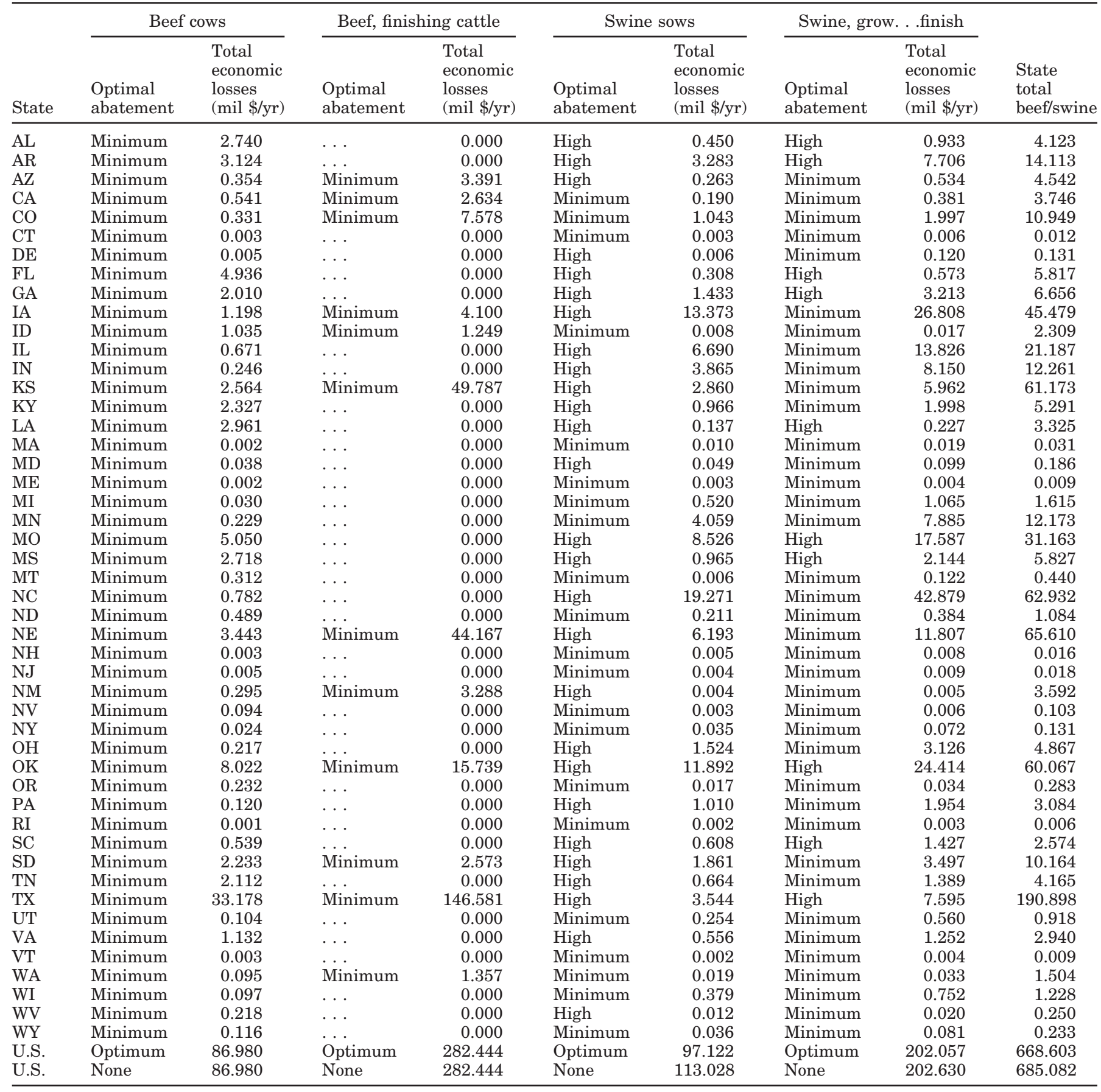

in the absence of heat abatement and $\$ 1.7$ billion under optimum heat abatement intensity. The actual number would be bounded by these two values and would be dependent on the proportion of all livestock raised under optimal heat abatement intensity. Considering the magnitude of the errors in estimating the effects of heat stress on animal performance, the national estimate of losses should be rounded to $\$ 2$ billion per year.
Nationally, losses under optimum heat abatement intensity average $71.9 \%$ of estimated losses without heat abatement (Figure 3). This proportion varies considerably across the nation depending on the nature of the production, the severity of heat stress, and the efficiency of the optimal system (Figure 3).

Overall, current heat abatement systems are not very resource efficient. Energy consumption of intense abate- 
Table 15. Optimal heat abatement intensity and total annual economic losses from heat stress in poultry and across all species.

\begin{tabular}{|c|c|c|c|c|c|c|c|c|}
\hline \multirow[b]{2}{*}{ State } & \multicolumn{2}{|c|}{ Poultry broilers } & \multicolumn{2}{|c|}{ Poultry, layers } & \multicolumn{2}{|c|}{ Poultry, turkey } & \multirow[b]{2}{*}{$\begin{array}{l}\text { State } \\
\text { total } \\
\text { poultry }\end{array}$} & \multirow[b]{2}{*}{$\begin{array}{l}\text { State } \\
\text { total } \\
\text { all animals }\end{array}$} \\
\hline & $\begin{array}{l}\text { Optimal } \\
\text { abatement }\end{array}$ & $\begin{array}{l}\text { Total } \\
\text { economic } \\
\text { losses } \\
(\mathrm{mil} \$ / \mathrm{yr})\end{array}$ & $\begin{array}{l}\text { Optimal } \\
\text { abatement }\end{array}$ & $\begin{array}{l}\text { Total } \\
\text { economic } \\
\text { losses } \\
(\mathrm{mil} \$ / \mathrm{yr})\end{array}$ & $\begin{array}{l}\text { Optimal } \\
\text { abatement }\end{array}$ & $\begin{array}{l}\text { Total } \\
\text { economic } \\
\text { losses } \\
(\mathrm{mil} \$ / \mathrm{yr})\end{array}$ & & \\
\hline $\mathrm{AL}$ & Minimum & 7.89 & High & 3.476 & & 0.000 & 11.367 & 21.727 \\
\hline $\mathrm{AR}$ & Minimum & 8.71 & High & 4.762 & High & 3.305 & 16.772 & 41.659 \\
\hline $\mathrm{AZ}$ & & 0.00 & & 0.000 & $\ldots$ & 0.000 & 0.000 & 19.994 \\
\hline $\mathrm{CA}$ & Minimum & 0.81 & High & 2.446 & & 0.000 & 3.256 & 131.974 \\
\hline $\mathrm{CO}$ & $\ldots$ & 0.00 & High & 0.234 & Minimum & 0.255 & 0.489 & 15.656 \\
\hline CT & & 0.00 & High & 0.180 & Minimum & 0.001 & 0.181 & 1.236 \\
\hline $\mathrm{DE}$ & Minimum & 0.57 & High & 0.202 & Minimum & 0.001 & 0.769 & 1.788 \\
\hline FL & Minimum & 1.09 & High & 4.678 & $\ldots$ & 0.000 & 5.765 & 63.841 \\
\hline GA & Minimum & 8.03 & High & 6.392 & & 0.000 & 14.422 & 41.892 \\
\hline IA & $\ldots$ & 0.00 & High & 3.924 & Minimum & 0.334 & 4.258 & 73.673 \\
\hline ID & $\ldots$ & 0.00 & High & 0.039 & & 0.000 & 0.039 & 13.294 \\
\hline IL & $\ldots$ & 0.00 & High & 0.586 & Minimum & 0.162 & 0.748 & 37.337 \\
\hline IN & $\ldots$ & 0.00 & High & 2.905 & Minimum & 0.516 & 3.421 & 30.094 \\
\hline $\mathrm{KS}$ & & 0.00 & High & 0.297 & Minimum & 0.374 & 0.671 & 76.047 \\
\hline $\mathrm{KY}$ & Minimum & 1.01 & High & 0.834 & $\ldots$ & 0.000 & 1.839 & 29.644 \\
\hline LA & $\ldots$ & 0.00 & High & 0.968 & & 0.000 & 0.968 & 28.107 \\
\hline MA & & 0.00 & High & 0.022 & Minimum & 0.001 & 0.023 & 1.149 \\
\hline MD & Minimum & 0.59 & High & 0.412 & Minimum & 0.015 & 1.021 & 8.750 \\
\hline ME & $\ldots$ & 0.00 & High & 0.155 & & 0.000 & 0.155 & 1.208 \\
\hline MI & & 0.00 & High & 0.359 & Minimum & 0.004 & 0.363 & 14.487 \\
\hline MN & Minimum & 0.05 & High & 0.969 & Minimum & 0.890 & 1.913 & 43.989 \\
\hline MO & Minimum & 1.37 & High & 1.500 & Minimum & 0.220 & 3.093 & 65.168 \\
\hline MS & Minimum & 7.03 & High & 2.655 & $\ldots$ & 0.000 & 9.684 & 27.665 \\
\hline MT & & 0.00 & High & 0.012 & & 0.000 & 0.012 & 1.029 \\
\hline $\mathrm{NC}$ & Minimum & 2.62 & High & 2.120 & Minimum & 2.576 & 7.316 & 80.356 \\
\hline ND & & 0.00 & & 0.000 & & 0.000 & 0.000 & 3.597 \\
\hline $\mathrm{NE}$ & Minimum & 0.02 & High & 2.270 & Minimum & 0.458 & 2.744 & 81.562 \\
\hline $\mathrm{NH}$ & $\ldots$ & 0.00 & High & 0.013 & Minimum & 0.000 & 0.013 & 1.620 \\
\hline NJ & $\ldots$ & 0.00 & High & 0.168 & Minimum & 0.001 & 0.169 & 1.122 \\
\hline NM & $\ldots$ & 0.00 & $\ldots$ & 0.000 & $\ldots$ & 0.000 & 0.000 & 27.319 \\
\hline NV & & 0.00 & & 0.000 & & 0.000 & 0.000 & 1.217 \\
\hline NY & Minimum & 0.00 & High & 0.207 & Minimum & 0.005 & 0.213 & 24.912 \\
\hline $\mathrm{OH}$ & Minimum & 0.07 & High & 3.130 & Minimum & 0.117 & 3.320 & 27.447 \\
\hline OK & Minimum & 2.08 & High & 1.449 & High & 0.903 & 4.430 & 91.508 \\
\hline OR & & 0.00 & High & 0.182 & & 0.000 & 0.182 & 4.716 \\
\hline PA & Minimum & 0.23 & High & 2.318 & Minimum & 0.263 & 2.808 & 50.768 \\
\hline RI & & 0.00 & High & 0.003 & & 0.000 & 0.003 & 0.082 \\
\hline $\mathrm{SC}$ & Minimum & 0.98 & High & 1.258 & Minimum & 0.823 & 3.056 & 9.927 \\
\hline SD & & 0.00 & High & 0.313 & Minimum & 0.230 & 0.543 & 22.622 \\
\hline $\mathrm{TN}$ & Minimum & 0.65 & High & 0.254 & & 0.000 & 0.907 & 20.659 \\
\hline TX & Minimum & 6.82 & High & 8.275 & High & 1.123 & 16.214 & 342.390 \\
\hline UT & & 0.00 & High & 0.145 & & 0.000 & 0.145 & 4.601 \\
\hline VA & Minimum & 0.97 & High & 0.611 & Minimum & 1.558 & 3.134 & 22.565 \\
\hline VT & $\ldots$ & 0.00 & High & 0.011 & Minimum & 0.000 & 0.011 & 5.387 \\
\hline WA & & 0.00 & High & 0.283 & & 0.000 & 0.283 & 12.767 \\
\hline WI & Minimum & 0.03 & High & 0.282 & Minimum & 0.056 & 0.366 & 62.305 \\
\hline WV & Minimum & 0.21 & High & 0.137 & Minimum & 0.160 & 0.510 & 2.364 \\
\hline WY & & 0.00 & High & 0.001 & & 0.000 & 0.001 & 0.352 \\
\hline U.S. & Optimum & 51.809 & Optimum & 61.437 & Optimum & 14.351 & 127.597 & $1,693.572$ \\
\hline U.S. & None & 51.809 & None & 98.091 & None & 14.685 & 164.585 & $2,356.350$ \\
\hline
\end{tabular}

ment systems is very significant. Physical efficiency is also linked closely to significant water usage. In dairy, for example, the use of fans and water sprinklers requires an additional $200 \mathrm{~L} / \mathrm{d}$ of water per cow (Igono et al., 1987). Promising results have recently been reported from research aimed at improving the cooling efficiency of current systems (Brouk et al., 2002a, 2000b). These improvements, however, require even larger volumes of water usage, which could exacerbate water usage problems in the expanding but dry regions of the United States. Clearly, additional research targeted at developing more resource efficient systems is needed. 


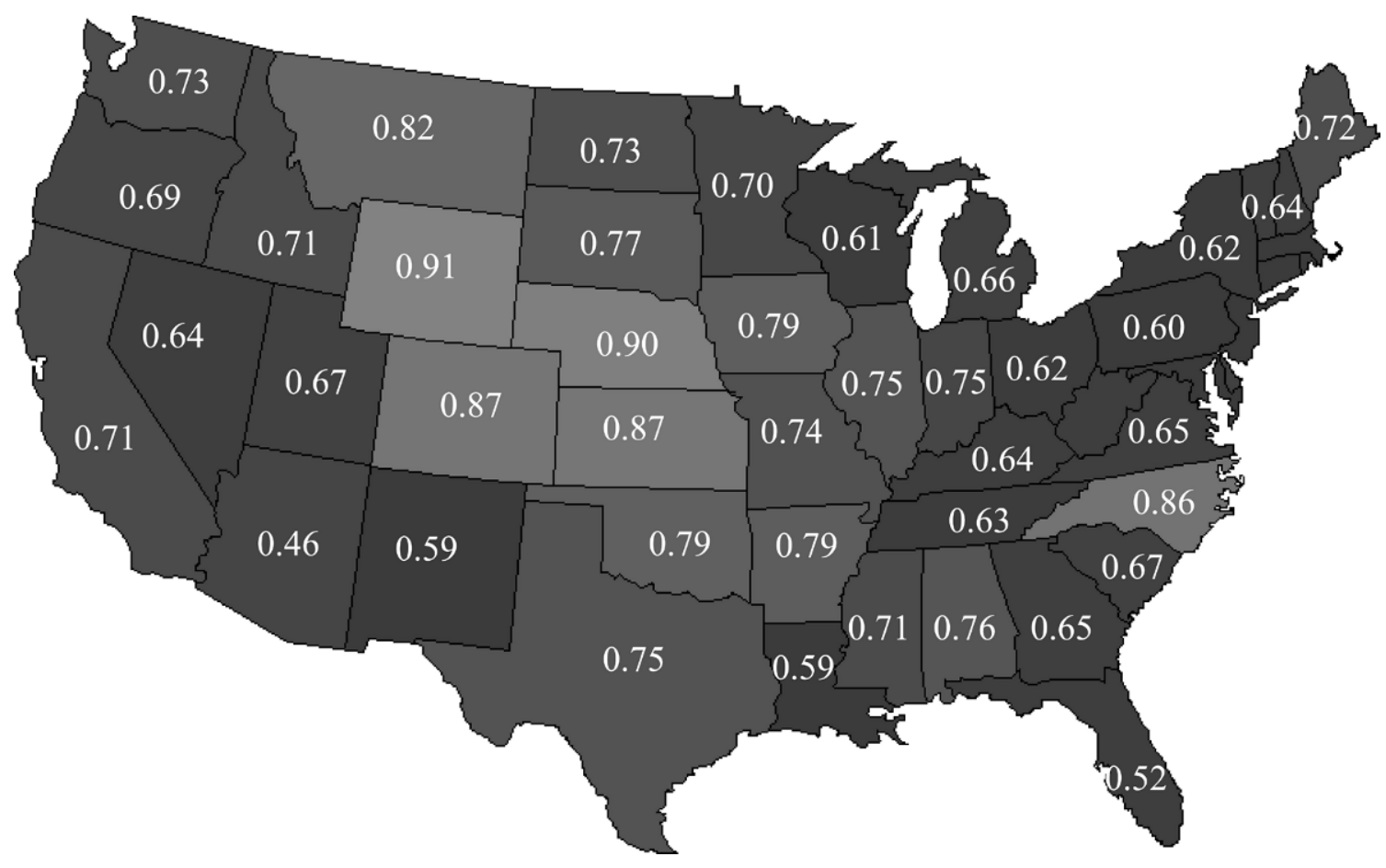

Figure 3. Ratio of total economic losses from heat stress under optimal heat abatment intensity to total economic losses in the absence of heat abatement per state in the continental United States.

\section{Limitations}

Some of the limitations to our knowledge on the effects of heat stress on animal productivity have been previously identified. There are many areas in which the mechanisms of heat stress are relatively well understood but for which the quantification of the response is poor (e.g., animal mortality). The paucity of information regarding the probability of mortality across major farm species given specific environmental conditions makes the quantification of this loss difficult. The integration of all major factors involved in creating heat stress is still very much incomplete. The THI scale is a weighted average of dry-bulb temperature $(65 \%)$ and wet-bulb temperature (35\%). Possibly, the weights assigned to each component should vary among species (Ravagnolo and Mistal, 2000) and may include nonlinear terms. The carryover effects of heat stress and the acclimation of animals seem important, yet the quantification of these two processes is difficult and generally lacking.

The model that we developed had as a primary objective the quantification of the total economic losses to heat stress across all major food-producing animals in the United States. Aggregating weather data to the state level induced some errors that were negligible in this context. There is a need, however, to design models for decision support at the farm level. These models will require much less aggregated weather data because enough climatic variation exists within many states to induce variation in the optimal cooling system within states and species.

\section{CONCLUSIONS}

Across the United States, heat stress results in estimated total annual economic losses to livestock industries that are between $\$ 1.69$ and $\$ 2.36$ billion. Of these losses, $\$ 897$ to $\$ 1500$ million occur in the dairy industry, $\$ 370$ million in the beef industry, $\$ 299$ to $\$ 316$ million in the swine industry, and $\$ 128$ to $\$ 165$ million in the poultry industry.

\section{ACKNOWLEDGMENTS}

We are thankful to D. Levis and S. Moeller, Department of Animal Sciences, The Ohio State University, for their assistance in developing the swine section of the model, to G. Betton, Venture Milling, division of Perdue Farms Inc. for his help with poultry data, and to J. Firkins, Department of Animal Sciences, The Ohio State University, for his helpful comments on a prior version of this paper. 


\section{APPENDIX}

\section{Computation of $\mathrm{THI}_{\mathrm{load}}$}

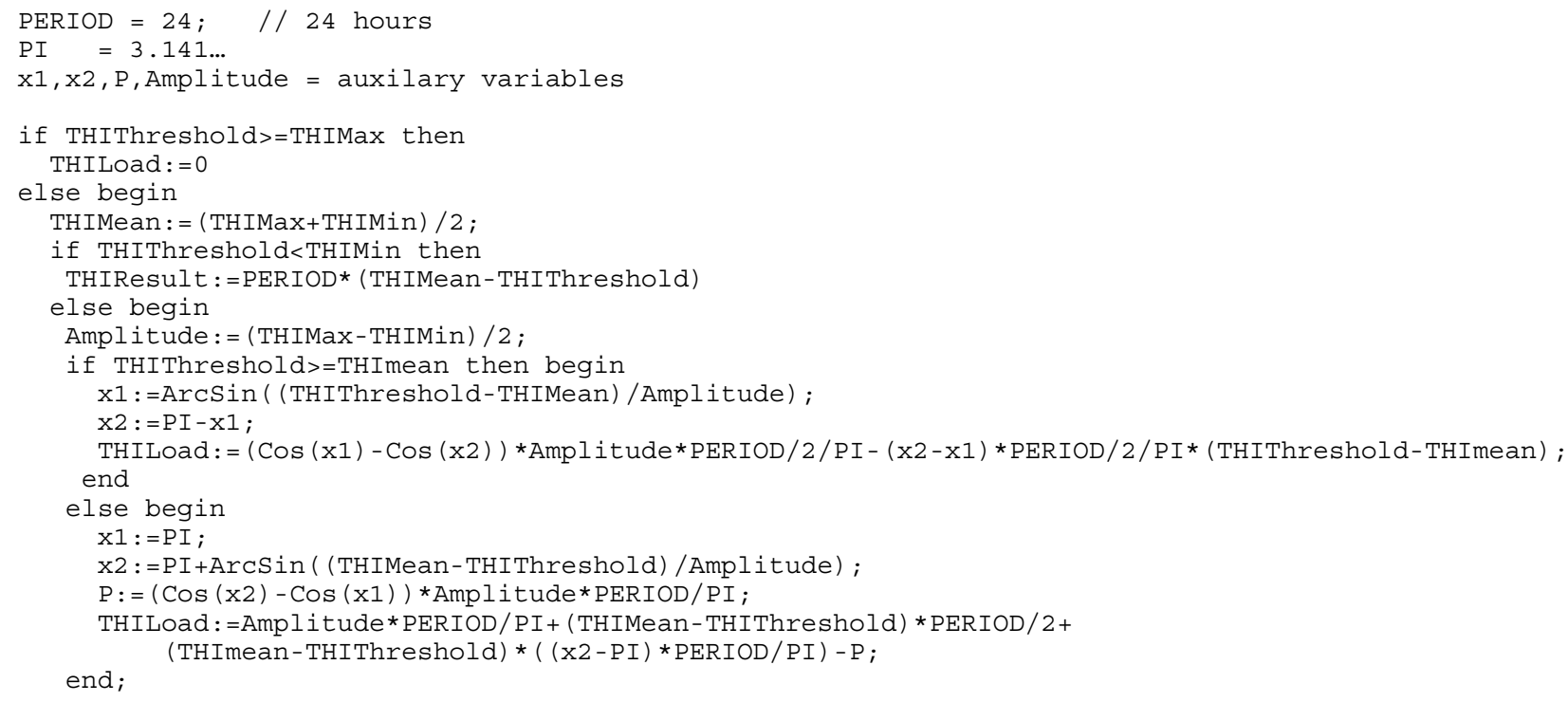

\section{Computation of the duration of heat stress}

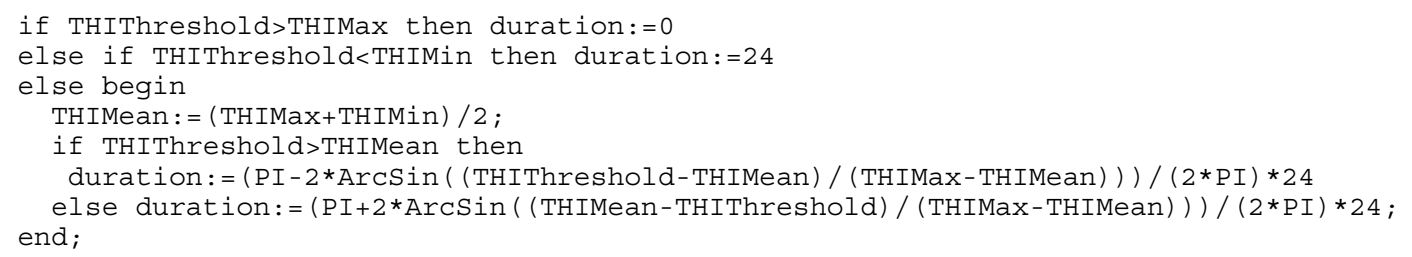

\section{REFERENCES}

al-Katanani, Y. M., D. W. Webb, and P. J. Hansen. 1999. Factors affecting seasonal variation in 90-day nonreturn rate to first service in lactating Holstein cows in a hot climate. J. Dairy Sci. 82:2611-2616.

Altan, O., A. Altan, I. Oguz, A. Pabuccuoglu, and S. Konyalioglu. 2000. Effects of heat stress on growth, some blood variables and lipid oxidation in broilers exposed to high temperature at an early age. Br. Poult. Sci. 41:489-493.

Ames, D. R. 1980. Thermal environment affects livestock performance. BioScience 30:457-470.

Arjona, A. A., D. M. Denbow, and W. D. Weaver Jr. 1990. Neonatallyinduced thermotolerance: physiological responses. Comp. Biochem. Physiol. A 95:393-399.

Armstrong, D. V. 1994. Heat stress interaction with shade and cooling. J. Dairy Sci. 77:2044-2050.

Armstrong, D. V., P. E. Hillman, M. J. Meyer, J. F. Smith, S. R. Stokes, and J. P. Harner. 1999. Heat stress management in freestall barns in the western U. S. Pages 87-98 in Proc. of Western Dairy Mgt. Conf., Las Vegas, NV.

Ax, R. L., G. R. Gilbert, and G. E. Shook. 1987. Sperm in poor quality semen from bulls during heat stress have a lower affinity for binding hydrogen-3 heparin. J. Dairy Sci. 70:195-200.

Barash, H., N. Silanikove, A. Shamay, and E. Ezra. 2001. Interrelationships among ambient temperature, day length, and milk yield in dairy cows under a Mediterranean climate. J. Dairy Sci. 84:2314-2320.

Berman, A., Y. Folman, M. Karen, M. Maman, Z. Herz, D. Wolfenson, A. Arieli, and Y. Graber. 1985. Upper critical temperatures and forced ventilation effects for high-yielding dairy cows in a subtropical climate. J. Dairy Sci. 68:1488-1495.

Biggers, B. G., R. D. Geisert, R. P. Wetteman, and D. S. Buchanan. 1987. Effect of heat stress on early embryonic development in the beef cow. J. Anim. Sci. 64:1512-1518.

Bogin, E., Y. Avidar, V. Pech-Waffenschmidt, Y. Doron, B. A. Israeli, and E. Kevhayev. 1996. The relationship between heat stress, survivability and blood composition of the domestic chicken. Eur. J. Clin. Chem. Biochem. 34:463-469.

Bollengier-Lee, S., M. A. Mitchell, D. B. Utomo, P. E. Williams, and C. C. Whitehead. 1998. Influence of high dietary vitamin E supplementation on egg production and plasma characteristics in hens subjected to heat stress. Br. Poult. Sci. 39:106-112.

Bollengier-Lee, S., P. E. Williams, and C. C. Whitehead. 1999. Optimal dietary concentration of vitamin $\mathrm{E}$ for alleviating the effect of heat stress on egg production in laying hens. Br. Poult. Sci. 40:102-107.

Brouk, M. J., J. F. Smith, and J. P. Harner. 2002a. Effect of sprinkling frequency and airflow on respiration rate, skin temperature and body temperature of heat stressed dairy cattle. J. Dairy Sci. 85:43. (Abstr.)

Brouk, M. J., J. F. Smith, and J. P. Harner. 2002b. Effect of utilizing evaporative cooling in tie-stall dairy barns equipped with tunnel 
ventilation on respiration rates and body temperatures of lactating dairy cattle. J. Dairy Sci. 85:43. (Abstr.)

Bull, R. P., P. C. Harrison, G. L. Riskowsi, and H. W. Gonyou. 1997. Preference among cooling systems by gilts under heat stress. J. Anim. Sci. 75:2078-2083.

Collier, R. J., D. K. Beede, W. W. Thatcher, L. A. Israel, and C. J. Wilcox. 1982. Influences of environment and its modification on dairy animal health and production. J. Dairy Sci. 65:2213-2227.

Collier, R. J., S. G. Doelger, H. H. Head, W. W. Thatcher, and C. J. Wilcox. 1982. Effects of heat stress during pregnancy on maternal hormone concentrations, calf birth weight and postpartum milk yield of Holstein cows. J. Anim. Sci. 54:309-319.

Collin, A., J. van Milgen, S. Dubois, and J. Noblet. 2001. Effect of high temperature on feeding behaviour and heat production in group-housed young pigs. Br. J. Nutr. 86:63-70.

Cooper, M. A., and K. W. Washburn. 1998. The relationships of body temperature to weight gain, feed consumption, and feed utilization in broilers under heat stress. Poult. Sci. 77:237-242.

Coppock, C. E., P. A. Grant, S. J. Portzer, D. A. Charles, and A. Escobosa. 1982. Lactating dairy cow responses to dietary sodium, chloride, and bicarbonate during hot weather. J. Dairy Sci. 65:566-576.

Dale, N. M., and H. L Fuller. 1980. Effect of diet composition on feed intake and growth of chicks under heat stress. II. Constant vs. cycling temperatures. Poult. Sci. 59:1434-1441.

D'Allaire, S., R. Drolet, and D. Brodeur. 1996. Sow mortality associated with high ambient temperatures. Can. Vet. J. 37:237-239.

De Basilio, V., M. Vilarino, S. Yahav, and M. Picard. 2001. Early age thermal conditioning and a dual feeding program for male broilers challenged by heat stress. Poult. Sci. 80:29-36.

Drost, M., J. D. Ambrose, M. J. Thatcher, C. K. Cantrell, K. E. Wolfsdorf, J. F. Hasler, and W. W. Thatcher. 1999. Conception rates after artificial insemination or embryo transfer in lactating dairy cows during summer in Florida. Theriogenology 52:1161-1167.

Drost, M. J., and W. W. Thatcher. 1987. Heat stress in dairy cows. Its effect on reproduction. Vet. Clin. North Am. Food Anim. Pract. 3:609-618.

Du Preez, J. H. 2000. Parameters for the determination and evaluation of heat stress in dairy cattle in South Africa. Onderstepoort J. Vet. Res. 67:263-271.

Du Preez, J. H., W. H. Giesecke, and P. J. Hattingh. 1990. Heat stress in dairy cattle and other livestock under southern African conditions. I. Temperature-humidity index mean values during the four main seasons. Onderstepoort J. Vet. Res. 57:77-87.

Du Preez, J. H., W. H. Giesecke, P. J. Hattingh, and B. E. Eisenberg. 1990. Heat stress in dairy cattle under southern African conditions. II. Identification of areas of potential heat stress during summer by means of observed true and predicted temperaturehumidity index values. Onderstepoort. J. Vet. Res. 57:183-187.

Du Preez, J. H., P. J. Hattingh, W. H. Giesecke, and B. E. Eisenberg. 1990. Heat stress in dairy cattle and other livestock under southern African conditions. III. Monthly temperature-humidity index mean values and their significance in the performance of dairy cattle. Onderstepoort J. Vet. Res. 57:243-248.

Du Preez, J. H., J. J. Willemse, and H. Van Ark. 1994. Effect of heat stress on conception in a dairy-herd model in the Natal highlands of South Africa. Onderstepoort J. Vet. Res. 61:1-6.

el-Gendy, E., and K. W. Washburn. 1995. Genetic variation in body temperature and its response to short-term acute heat stress in broilers. Poult. Sci. 74:225-230.

Emery, D. A., P. Vohra, R. A. Ernst, and S. R. Morrison. 1984. The effect of cyclic and constant ambient temperatures on feed consumption, egg production, egg weight, and shell thickness of heat. Poult Sci. 63:2027-2035.

Ernst, R. A., W. W. Weathers, and J. Smith. 1984. Effects of heat stress on day-old broiler chicks. Poult Sci. 63:1719-1721.

Evans, R. D., R. K. Edson, K. L. Watkins, J. L. Robertson, J. B. Meldrum, and M. N. Novilla. 2000. Turkey knockdown in successive flocks. Avian Dis. 44:730-736.

Fishman, G. S. 1978. Principles of Discrete Event Simulation. John Wiley and Sons, New York.
Flamenbaum, I., D. Wolfenson, P. L. Kunz, M. Maman, and A. Berman. 1995. Interactions between body conditions at calving and cooling of dairy cows during lactations in summer. J. Dairy Sci. 78:2221-2229.

Flamenbaum, I., D. Wolfenson, M. Maman, and A. Berman. 1986. Cooling dairy cattle by a combination of sprinkling and forced ventilation and its implementation in the shelter system. J. Dairy Sci. 69:3140-3147.

Flowers, B., T. C. Cantley, M. J. Martin, and B. N. Day. 1989. Effect of elevated ambient temperatures on puberty in gilts. J. Anim. Sci. 67:779-784.

Folman, Y., M. Rosenberg, I. Ascarelli, M. Kaim, and Z. Herz. 1983. The effect of dietary and climatic factors on fertility, and on plasma progesterone and oestradiol-17 beta levels in dairy cows. J. Steroid Biochem. 19:863-868.

Fuquay, J. W. 1981. Heat stress as it affects animal production. J. Anim. Sci. 52:164-174.

Gaughan, J. B., T. L. Mader, S. M. Holt, M. J. Josey, and K. J. Rowan. 1999. Heat tolerance of Boran and Tuli crossbred steers. J. Anim. Sci. 77:2398-2405.

Giesecke, W. H. 1985. The effect of stress on udder health of dairy cows. Onderstepoort J. Vet. Res. 52:175-193.

Gross, T. S., D. J. Putney, F. W. Bazer, and W. W. Thatcher. 1989. Effect of in-vitro heat stress on prostaglandin and protein secretion by endometrium from pregnant and cyclic gilts at day 14 after oestrus. J. Reprod. Fertil. 85:541-550.

Hahn, G. L. 1985. Management and housing of farm animals in hot environment. Pages 151-176 in Stress Physiology of Livestock. Ungulates, Vol. 2. M. K. Yousef, ed. CRC Press, Boca Raton, FL.

Hammond, A. C., C. C. Chase Jr., E. J. Bowers, T. A. Olson, and R. D. Randel. 1998. Heat tolerance in Tuli-, Senepol-, and Brahmansired F1 Angus heifers in Florida. J. Anim. Sci. 76:1568-1577.

Hansen, P. J., M. Drost, R. M. Rivera, F. F. Paula-Lopes, Y. M. alKatanani, C. E. Krininger 3rd and C. C. Chase, Jr. 2001. Adverse impact of heat stress on embryo production: Causes and strategies for mitigation. Theriogenology 55:91-103.

Hennessy, D. P., and P. E. Williamson. 1984. Stress and summer infertility in pigs. Aust. Vet. J. 61:212-215.

Her, E., D. Wolfenson, I. Flamenbaum, Y. Folman, M. Kaim, and A. Berman. 1988. Thermal, productive, and reproductive responses of high yielding cows exposed to short-term cooling in summer. J. Dairy Sci. 71:1085-1092.

Holter, J. B., J. W. West, and M. L. McGilliard. 1997. Predicting ad libitum dry matter intake and yield of Holstein cows. J. Dairy Sci. 80:2188-2199.

Holter, J. B., J. W. West, M. L. McGilliard, and A. N. Pell. 1996. Predicting ad libitum dry matter intake and yields of Jersey cows. J. Dairy Sci. 79:912-921.

Igono, M. O., G. Bjotvedt, and H. T. Sanford-Crane. 1992. Environmental profile and critical temperature effects on milk production of Holstein cows in desert climate. Int. J. Biometeorol. 36:77-87.

Igono, M. O., H. D. Johnson, B. J. Steevens, G. F. Krause, and M. D. Shanklin. 1987. Physiological, productive, and economic benefits of shade, spray, and fan system versus shade for Holstein cows during summer heat. J. Dairy Sci. 70:1069-1079.

Ingraham, R. H., R. W. Stanley, and W. C. Wagner. 1976. Relationship of temperature and humidity to conception rate of Holstein cows in Hawaii. J. Dairy Sci. 59:2086-2090.

Johnston, L. J., M. Ellis, G. W. Libal, V. B. Mayrose, and W. C. Weldon. 1999. Effect of room temperature and dietary amino acid concentration on performance of lactating sows. NCR-89 Committee on Swine Management. J. Anim. Sci. 77:1638-1644.

Kassim, H., and A. H. Sykes. 1982. The respiratory responses of the fowl to hot climates. J. Exp. Biol. 97:301-309.

Knapp, D. M., and R. R. Grummer. 1991. Response of lactating dairy cows to fat supplementation during heat stress. J. Dairy Sci. 74:2573-2579.

Kojima, T., K. Udagawa, A. Onishi, H. Iwahashi, and Y. Komatsu. 1996. Effect of heat stress on development in vitro and in vivo and on synthesis of heat shock proteins in porcine embryos. Mol. Reprod. Dev. 43:452-457. 
Lewis, G. S., W. W. Thatcher, E. L. Bliss, M. Drost, and R. J. Collier. 1984. Effects of heat stress during pregnancy on postpartum reproductive changes in Holstein cows. J. Anim. Sci. 58:174-186.

Liao, C. W., and T. L. Veum. 1994. Effects of dietary energy intake by gilts and heat stress from days 3 to 24 or 30 after mating on embryo survival and nitrogen and energy balance. J. Anim. Sci. 72:2369-2377.

Lin, J. C., B. R. Moss, J. L. Koon, C. A. Floyd, R. L. Smith III, K. A. Cummins, and D. A. Coleman. 1998. Comparison of various fan, sprinkler, and mister systems in reducing heat stress in dairy cattle. Appl. Eng. Agric. 14:177-182.

Linvill, D. E., and F. E. Pardue. 1992. Heat stress and milk production in the South Carolina coastal plains. J. Dairy Sci. 75:2598-2604.

Lippke, H. 1975. Digestibility and volatile fatty acids in steers and wethers at 21 and $32 \mathrm{C}$ ambient temperature. J. Dairy Sci. 58:1860-1864.

Lobo, P. 2001. USA feed market. Feed Mgmt. 52:6-12.

Mader, T. 2002. Environmental stress in beef cattle. J. Anim. Sci. 80:55. (Abstr.)

Mader, T. L., J. M. Dahlquist, G. L. Hahn, and J. B. Gaughan. 1999. Shade and wind barrier effects on summertime feedlot cattle performance. J. Anim. Sci. 77:2065-2072.

May, J. D. 1982. Effect of dietary thyroid hormone on survival time during heat stress. Poult. Sci. 61:706-709.

May, J. D., J. W. Deaton, and S. L. Branton. 1987. Body temperature of acclimated broilers during exposure to high temperature. Poult. Sci. 66:378-380.

Mayer, D. G., T. M. Davison, M. R. McGowan, B. A. Young, A. L. Matschoss, A. B. Hall, P. J. Goodwin, N. N. Jonsson, and J. B. Gaughan. 1999. Extent and economic effect of heat loads on dairy cattle production in Australia. Aust. Vet. J. 77:804-808.

McDaniel, C. D., R. K. Bramwell, J. L. Wilson, and B. Howarth Jr. 1995. Fertility of male and female broiler breeders following exposure to elevated ambient temperatures. Poult. Sci. 74:1029-1038.

McDouglad, L. R., and T. E. McQuistion. 1980. Mortality from heat stress in broiler chickens influenced by anticoccidial drugs. Poult. Sci. 59:2421-2423.

McDowell, R. E., N. W. Hooven, and J. K. Camoens. 1976. Effects of climate on performance of Holsteins in first lactation. J. Dairy Sci. 59:956-964.

McDowell, R. E., J. C. Wilk, and C. W. Talbott. 1996. Economic viability of crosses of Bos Taurus and Bos indicus for dairying in warm climates. J. Dairy Sci. 79:1292-1303.

McGlone, J. J., W. F. Stansbury, and L. F. Tribble. 1987. Effects of heat and social stressors and within-pen weight variation on young pig performance and agonistic behavior. J. Anim. Sci. 65:456-462.

McGlone, J. J., W. F. Stansbury, and L. F. Tribble. 1988. Management of lactating sows during heat stress: effects of water drip, snout coolers, floor type and a high energy-density diet. J. Anim. Sci. $66: 885-891$

McGlone, J. J., W. F. Stansbury, L. F. Tribble, and J. L. Morrow. 1988. Photoperiod and heat stress influence on lactating sow performance and photoperiod effects on nursery pig performance. J. Anim. Sci. 66:1915-1919.

McKee, J. S., P. C. Harrison, and G. L. Riskowski. 1997. Effects of supplemental ascorbic acid on the energy conversion of broiler chicks during heat stress and feed withdrawal. Poult. Sci. 76:1278-1286.

McKee, S. R., and A. R. Sams. 1997. The effect of seasonal heat stress on rigor development and the incidence of pale, exudative turkey meat. Poult. Sci. 76:1616-1620.

McNaughton, J. L., J. D. May, F. N. Reece, and J. W. Deaton. 1978. Lysine requirement of broilers as influenced by environmental temperatures. Poult. Sci. 57:57-67.

Means, S. L., R. A. Bucklin, R. A., Nordstedt, D. K. Beede, D. R. Bray, C. J. Wilcox, and W. K. Sanchez. 1992. Water application rates for a sprinkler and fan dairy cooling system in hot-humid climates. Appl. Eng. Agric. 8:375-379.

Meyerhoeffer, D. C., R. P. Wettemann, S. W. Coleman, and M. E. Wells. 1985. Reproductive criteria of beef bulls during and after exposure to increased ambient temperature. J. Anim. Sci. 60:352-357.

Mitchell, M. A., and P. J. Kettlewell. 1998. Physiological stress and welfare of broiler chickens in transit: solutions not problems! Poult. Sci. 77:1803-1814.

Mitlohner, F. M., J. L. Morrow, J. W. Dailey, S. C. Wilson, M. L. Galyean, M. F. Miller, and J. J. McGlone. 2001. Shade and water misting effects on behavior, physiology, performance, and carcass traits of heat-stressed feedlot cattle. J. Anim. Sci. 79:2327-2335.

Monty, D. E. Jr., and L. K. Wolf. 1974. Summer heat stress and reduced fertility in Holstein-Friesian cows in Arizona. Am. J. Vet. Res. 35:1495-1500.

Moore, R. B., J. W. Fuquay, and W. J. Drapala. 1992. Effects of late gestation heat stress on postpartum milk production and reproduction in dairy cattle. J. Dairy Sci. 75:1877-1882.

Morrison, S. R. 1983. Ruminant heat stress: effect on production and means of alleviation. J. Anim. Sci. 57:1594-1600.

Morrison, S. R., H. Heitman, T. E. Bond, and P. Finn-Kelcey. 1966. The influence of humidty on growth rate and feed utilization of swine. Int. J. Biometerol. 10:163-175.

Morrison, S. R., H. Heitman, and T. E. Bond. 1969. Effect of humidity on swine at temperatures above optimum. Int. J. Biometerol. 13:135-149.

Morrison, S. R., H. Heitman, and R. L. Givens. 1973. Effects of diurnal air temperature cycles on growth and food conversion in pigs. Anim. Prod. 20:287-298.

Muiruri, H. K., and P. C. Harrison. 1991. Effect of roost temperature on performance of chickens in hot ambient environments. Poult. Sci. 70:2253-2258.

National Research Council. 1981. Effect of environment on nutrient requirements of domestic animals. Natl. Acad. Sci., Washington, DC.

Neuwirth, J. G., J. K. Norton, C. A. Rawlings, F. N. Thompson, and G. O. Ware. 1979. Physiologic responses of dairy calves to environmental heat stress. Int. J. Biometeorol. 23:243-254.

Nienaber, J. A., G. L. Hahn, and R. A. Eigenberg. 1999. Quantifying livestock responses for heat stress management: A review. Int. J. Biometeorol. 42:183-188.

Ominski, K. H., A. D. Kennedy, K. M. Wittenberg, and S. A. Mostaghi Nia. 2002. Physiological and production responses to feeding schedule in lactating dairy cows exposed to short-term, moderate heat stress. J. Dairy Sci. 85:730-737.

Owens, C. M., S. R. Mckee, N. S. Matthews, and A. R. Sams. The development of pale, exudative meat in two genetic lines of turkeys subjected to heat stress and its prediction by halothane screening. Poult. Sci. 79:430-435.

Ravagnolo, O., and I. Misztal. 2000. Genetic component of heat stress in dairy cattle, parameter estimation. J. Dairy Sci. 83:2126-2130.

Ravagnolo, O., I. Misztal, and G. Hoogenboom. 2000. Genetic component of heat stress in cattle, development of heat index function. J. Dairy Sci. 83:2120-2125.

Ray, D. E. 1989. Interrelationships among water quality, climate and diet on feedlot performance of steer calves. J. Anim. Sci. 67:357-363.

Ray, D. E., T. J. Halbach, and D. V. Armstrong. 1992. Season and lactation number effects on milk production and reproduction of dairy cattle in Arizona. J. Dairy Sci. 75:2976-2983.

Reilly, W. M., K. W. Koelkebeck, and P. C. Harrison. 1991. Performance evaluation of heat-stressed commercial broilers provided water-cooled floor perches. Poult. Sci. 70:1699-1703.

Renaudeau, D., and J. Noblet. 2001. Effects of exposure to high ambient temperature and dietary protein level on sow milk production and performance of piglets. J. Anim. Sci. 79:1540-1548.

Renaudeau, D., N. Quiniou, and J. Noblet. 2001. Effects of exposure to high ambient temperature and dietary protein level on performance of multiparous lactating sows. J. Anim. Sci. 79:1240-1249.

Richards, J. I. 1985. Milk production of Friesian cows subjected to high daytime temperatures when allowed food either ad lib or at night-time only. Trop. Anim. Health Prod. 17:141-152.

Robinson, J. B., D. R. Ames, and G. A. Milliken. 1986. Heat production of cattle acclimated to cold, thermoneutrality and heat when ex- 
posed to thermoneutrality and heat stress. J. Anim. Sci. 62:1434-1440.

Roth, Z., R. Median, R. Braw-Tal, and D. Wolfenson. 2000. Immediate and delayed effects of heat stress on follicular development and its association with plasma FSH and inhibin concentration in cows. J. Reprod. Fertil. 120:83-90.

Roth, Z., R. Meidan, A. Shaham-Albalancy, R. Braw-Tal, and D. Wolfenson. 2001. Delayed effect of heat stress on steroid production in medium-sized and preovulatory bovine follicles. Reproduction 121:745-751.

Salah, M. S., and H. H. Mogawer. 1990. Reproductive performance of Friesian cows in Saudi Arabia. II. Resting and service interval, conception rate, and number of services per conception. Beitr. Trop. Landwirtsch Veterinarmed. 28:85-91.

Sahin, K., and O. Kucuk. 2001. A simple way to reduce heat stress in laying hens as judged by egg laying, body weight gain and biochemical parameters. Acta Vet. Hung. 49:421-430.

Sahin, K., O. Ozbey, M. Onderci, G. Cikim, and M. H. Aysondu. 2002. Chromium supplementation can alleviate negative effects of heat stress on egg production, egg quality and some serum metabolites of laying Japanese quail. J. Nutr. 132:1265-1268.

Sandercock, D. A., R. R. Hunter, G. R. Nute, M. A. Mitchell, and P. M. Hocking. 2001. Acute heat stress-induced alterations in blood acid-base status and skeletal muscle membrane integrity in broiler chickens at two ages: implications for meat quality. Poult. Sci. 80:418-425.

Schneider, P. L., D. K. Beede, C. J. Wilcox, and R. J. Collier. 1984. Influence of dietary sodium and potassium bicarbonate and total potassium on heat-stressed lactating dairy cows. J. Dairy Sci. 67:2546-2553.

Schoenherr, W. D., T. S. Stahly, and G. L. Cromwell. 1989. The effects of dietary fat or fiber addition on yield and composition of milk from sows housed in a warm or hot environment. J. Anim. Sci. 67:482-495.

Settar, P., S. Yalcin, L. Turkmut, S. Ozkan, and A. Cahanar. 1999. Season by genotype interaction related to broiler growth rate and heat tolerance. Poult. Sci. 78:1353-1358.

Silanikove, N. 2000. Effects of heat stress on the welfare of extensively managed domestic ruminants. Livest. Prod. Sci. 67:1-18.

Spain, J. N., and D. E. Spiers. 1996. Effects of supplemental shade on thermoregulatory response of calves to heat challenge in a hutch environment. J. Dairy Sci. 79:639-646.

St-Pierre, N. R., and L. R. Jones. 2001. Forecasting herd structure and milk production for production risk management. J. Dairy Sci. 84:1805-1813.

Strickland, J. T., R. A. Bucklin, R. A. Nordstedt, D. K. Beede, and D. R. Bray. 1989. Sprinkler and fan cooling systems for dairy cows in hot, humid climates. Appl. Eng. Agric. 5:231-236.

Sykes, A. H., and A. R. Fataftha. 1985. Acclimation of the fowl to intermittent acute heat stress. Br. Poult. Sci. 27:289-300.

Sykes, A. H., and A. R. Fataftah. 1986. Effect of a change in environmental temperature on heat tolerance in laying fowl. Br. Poult. Sci. 27:307-316.

Sykes, A. H., and F. I. Salih. 1986. Effect of changes in dietary energy intake and environmental temperature on heat tolerance in the fowl. Br. Poult. Sci. 27:687-693.

Tadtiyanant, C., J. J. Lyons, and J. M. Vandepopuliere. 1991. Influence of wet and dry feed on laying hens under heat stress. Poult. Sci. 70:44-52.
Turner, L. W., J. P. Chastain, R. W. Hemken, R. S. Gates, and W. L. Crist. 1992. Reducing heat stress in dairy cows through sprinkler and fan cooling. Appl. Eng. Agric. 8:251-256.

West, J. W. 1994. Interactions of energy and bovine somatotropin with heat stress. J. Dairy Sci. 77:2091-2102.

Wettemann, R. P., and F. W. Bazer. 1985. Influence of environmental temperature on prolificacy of pigs. J. Reprod. Fertil. Suppl. 33:199-208.

Whiting, T. S., L. D. Andrews, M. H. Adams, and L. Stamps. 1991. Effects of sodium bicarbonate and potassium chloride drinking water supplementation. 2. Meat and carcass characteristics of broilers grown under thermoneutral and cyclic heat-stress conditions. Poult. Sci. 70:60-66.

Wiernusz, C. J., and R. G. Teeter. 1996. Acclimation effects on fed and fasted broiler thermobalance during thermoneutral and high ambient temperature exposure. Br. Poult. Sci. 37:677-687.

Wilson, S. J., C. J. Kirby, A. T. Koenigsfeld, D. H. Keisler, and M. C. Lucy. 1998. Effects of controlled heat stress on ovarian function of dairy cattle. 2. Heifers. J. Dairy Sci. 81:2132-2138.

Wilson, S. J., R. S. Marion, J. N. Spain, D. E. Spiers, D. H. Keisler, and M. C. Lucy. 1998. Effects of controlled heat stress on ovarian function of dairy cattle. 1. Lactating cows. J. Dairy Sci. 81:2124-2131.

Wise, M. E., D. V. Armstrong, J. T. Huber, R. Hunter, and F. Wiersma. 1988. Hormonal alterations in the lactating dairy cow in response to thermal stress. J. Dairy Sci. 71:2480-2485.

Wolfenson, D., D. Bachrach, M. Maman, Y. Graber, and I. Rozenboim. 2001. Evaporative cooling of ventral regions of the skin in heatstressed laying hens. Poult. Sci. 80:958-964.

Wolfenson, D., I. Flamenbaum, and A. Berman. 1988. Dry period heat stress relief effects on prepartum progesterone, calf birth weight, and milk production. J. Dairy Sci. 71:809-818.

Wolfenson, D., Y. F. Frei, N. Snapir, and A. Berman. 1979. Effect of diurnal or nocturnal heat stress on egg formation. Br. J. Poult. Sci. $20: 167-174$.

Wolfenson, D., B. J. Lew, W. W. Thatcher, Y. Graber, and R. Meidan. 1997. Seasonal and acute heat stress effects on steroid production by dominant follicles in cows. Anim. Reprod. Sci. 47:9-19.

Wolfenson, D., Z. Roth, and R. Meidan. 2000. Impaired reproduction in heat-stressed catlle: basic and applied aspects. Anim. Reprod. Sci. 2:60-61; 535-547.

Wolfenson, D., W. W. Thatcher, L. Badinga, J. D. Savio, R. Meidan, B. J. Lew, R. Braw-Tal, and A. Berman. 1995. Effect of heat stress on follicular development during the estrous cycle in lactating dairy cattle. Biol. Reprod. 52:1106-1113.

Yahav, S., and I. Plavnik. 1999. Effect of early-stage thermal conditioning and food restriction on performance and thermotolerance of male broiler chickens. Br. Poult. Sci. 40:120-126.

Yalcin, S., S. Ozkan, L. Turkmut, and P. B. Siegel. 2001a. Responses to heat stress in commercial and local broiler stocks. 1. Performance traits. Br. Poult. Sci. 42:149-152.

Yalcin, S., S. Ozkan, L. Turkmut, and P. B. Siegel. 2001b. Responses to heat stress in commercial and local broiler stocks. 2. Developmental stability of bilateral traits. Br. Poult Sci. 42:153-160.

Zoa-Mboe, A., H. H. Head, K. C. Bachman, F. Baccari, Jr., and C. J. Wilcox. 1989. Effects of bovine somatotropin on milk yield and composition, dry matter intake, and some physiological functions of Holstein cows during heat stress. J. Dairy Sci. 72:907-916. 